Florida International University FIU Digital Commons

$11-19-2000$

\title{
The effects of phosphorus and carbon additions on anaerobic microbial activity in peat soils of the Florida Everglades
}

Gisele Louise Colbert

Florida International University

DOI: $10.25148 /$ etd.FI14060872

Follow this and additional works at: https://digitalcommons.fiu.edu/etd

Part of the Biology Commons

\section{Recommended Citation}

Colbert, Gisele Louise, "The effects of phosphorus and carbon additions on anaerobic microbial activity in peat soils of the Florida Everglades" (2000). FIU Electronic Theses and Dissertations. 2402.

https://digitalcommons.fiu.edu/etd/2402 
FLORIDA INTERNATIONAL UNIVERSITY

Miami, Florida

THE EFFECTS OF PHOSPHORUS AND CARBON

ADDITIONS ON ANAEROBIC MICROBIAL ACTIVITY

IN PEAT SOILS OF THE FLORIDA EVERGLADES

A thesis submitted in partial fulfillment of the requirements for the degree of

MASTER OF SCIENCE

in

BIOLOGY

by

Gisele Louise Colbert

2000 
To: Dean Arthur W. Herriott

College of Arts and Sciences

This thesis, written by Gisele Louise colbert, and entitled The Effects of Phosphorus and Carbon Additions on Anaerobic Microbial Activity in Peat Soils of the Florida Everglades, having been approved in respect to style and intellectual content, is referred to you for judgment.

We have read this thesis and recommend that it be approved.

Joel Trexler

Rudolph Jaffe

Ronald Jones, Major Professor

Date of Defense: November 19, 1999

The thesis of Gisele Louise Colbert is approved.

Dean Arthur w. Herriott College of Arts and Sciences

Dean Richard L. Campbell Division of Graduate studies

Florida International University, 2000 


\section{DEDICATION}

I dedicate this thesis to my grandfather whose life time accomplishments encouraged me to further my education and to never stop learning. I also dedicate this thesis to my parents whose motivation, support and love made it possible for this work to be completed. 


\section{ACKNOWLEDGMENTS}

I would like to thank my committee members for their support and confidence in me. I wish to thank the people at SERC for all their help in the laboratory and field. Dr. Len Scinto, your knowledge, kindness, and help throughout my research and writing my thesis has been most appreciated. George Meichel, I could not have asked for a more knowledgeable and helpful research partner to work with throughout this endeavor. Finally I would like to thank my major professor, Dr. Ronald Jones, whose wisdom, guidance, understanding, and confidence in my abilities assured me that not only could I complete my Masters degree but that I could succeed with excellence in any challenge I take on. 
ABSTRACT OF THE THESIS

THE EFFECTS OF PHOSPHORUS AND CARBON ADDITIONS ON ANAEROBIC MICROBIAL ACTIVITY

IN PEAT SOILS OF THE FLORIDA EVERGLADES

\author{
by \\ Gisele L. Colbert \\ Florida International University, 2000 \\ Miami, Florida \\ Professor Ronald Jones, Major Professor
}

Human activities have altered the natural biogeochemical cycles of many elements to the extent that they are now treated as pollutants in many ecosystems. The Everglades of South Florida have been negatively impacted by two such elements, phosphorus and mercury. This study tested the hypothesis that increased phosphorus concentration contributes to conditions that lead to increased anaerobic microbial activity and microbial populations that might be linked to mercury methylation in Everglades peat soils. Soil was collected from a pristine Eleocharis marsh in the Shark River Slough area of Everglades National Park. Changes in microbial communities from aerobically-dominated to anaerobically-dominated processes were measured by reductions in redox potential, $\mathrm{CO}_{2}$ and $\mathrm{CH}_{4}$ evolution, enzyme activity, and bacterial density. The results indicate that in Everglades peat soil phosphorus level plays a 
significant role in shifting microbial communities from aerobically-dominated to anaerobically dominated processes. 
SECTION

PAGE

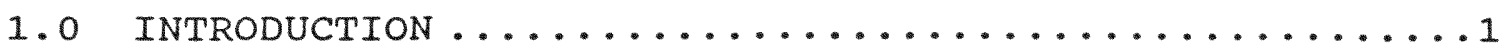

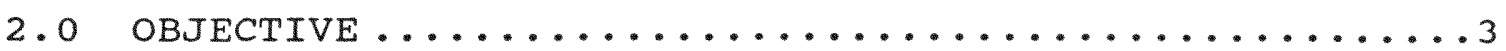

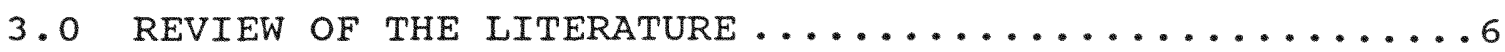

3.1 Characteristics of the Everglades Ecosystem ... 6

3.2 Anaerobic Microbial Metabolism ............ 7

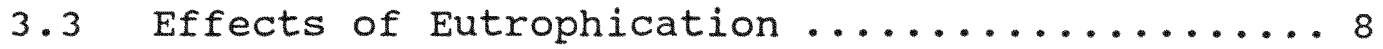

3.4 Transformations of Mercury and their Relevance

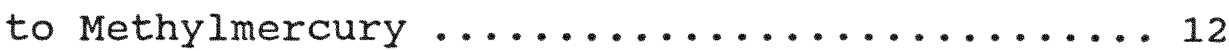

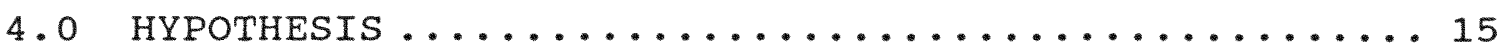

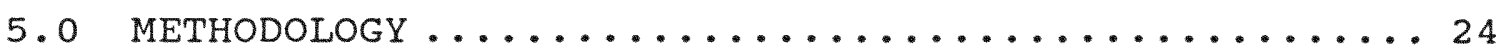

5.1 Field Samples and Column Preparation........ 24

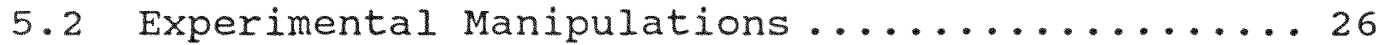

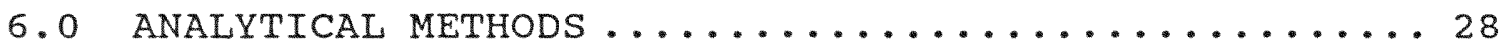

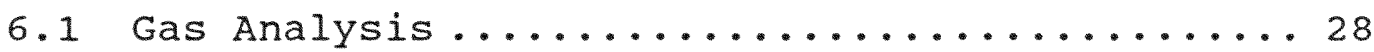

6.2 Enzyme Activity Analysis ................. 29

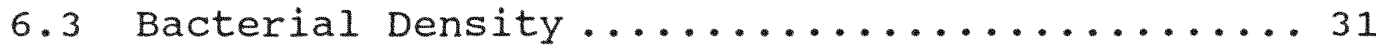

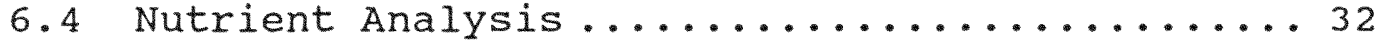

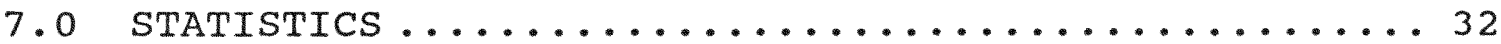

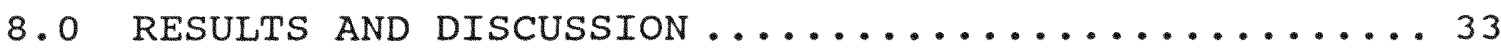

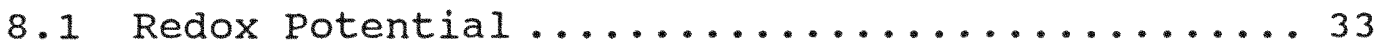

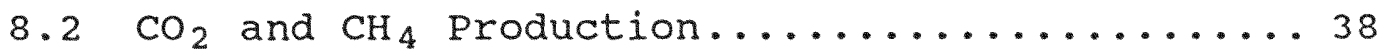

8.3 Enzyme Activity and Microbial Biomass ........4 47

8.4 Mercury Methylation ................... 58

9.0 CONCLUSIONS AND RELEVANCE .......................... 61

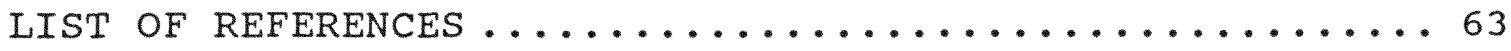




\section{LIST OF TABLES}

TABLE

PAGE

1. Effects of $\mathrm{P}$ additions on redox potential with no glucose addition at 1,10 and $100 u$ M $P$ concentrations..20

2. Effects of $P$ additions on redox potential with no glucose addition at 10,100 and $1000 u \mathrm{M}$

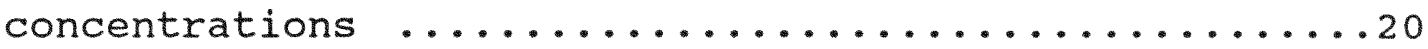

3. Chemical properties of soils used in this study .....25

4. ANOVA and Fisher's LSD table for the effects of

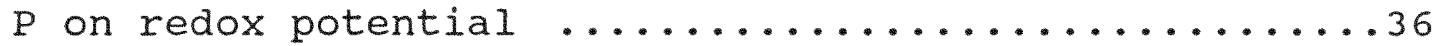

5. ANOVA and Fisher's LSD table for effects of $P$ on cumulative $\mathrm{CO}_{2}$ evolution after incubation for

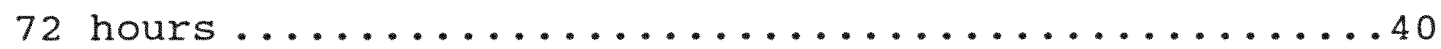

6. ANOVA and Fisher'S LSD table for effects of $P$ on cumulative $\mathrm{CH}_{4}$ evolution after incubation for

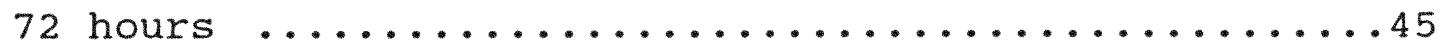

7. Student's T-Test table for effects of $\mathrm{p}$ on enzyme

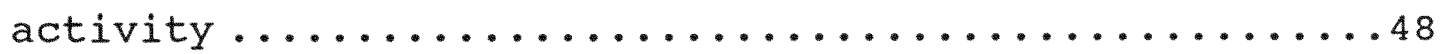

8. ANOVA table for the effects of $P$ on

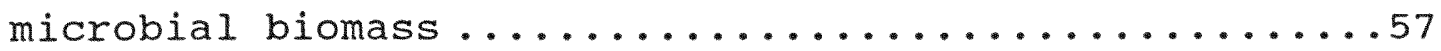




\section{LIST OF FIGURES}

FIGURE

PAGE

1. Map of Florida Everglades...................... 10

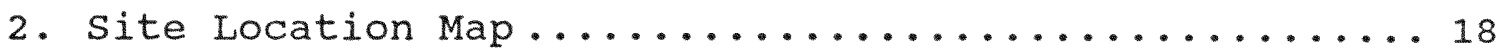

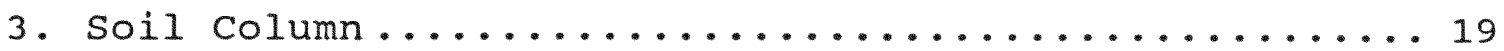

4. Effects of $P$ on redox potential for the first experiment conducted which used high $\mathrm{P}$ level additions and added glucose however the soil was not

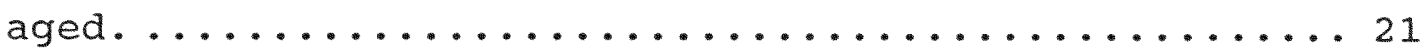

5. Effects of $P$ on redox potential for the second experiment conducted with glucose addition prior to

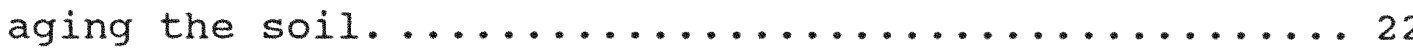

6. Effects of $\mathrm{P}$ on redox potential for experiments 1, 2,

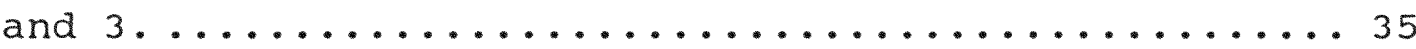

7. Effects of $\mathrm{PO}_{4}$ additions on cumulative $\mathrm{CO}_{2}$ evolution after incubation for 72 hours for experiments 1,2 and

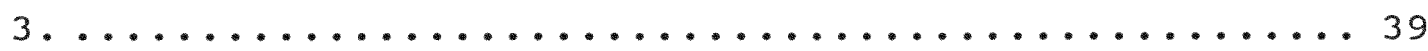

8. Effects of $\mathrm{PO}_{4}$ additions on cumulative $\mathrm{CO}_{4}$ evolution after incubation for 72 hours for experiments 1, 2 and

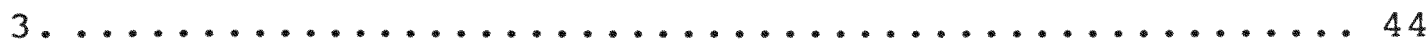

9. Effects of $\mathbf{P}$ on alkaline phosphatase activity in

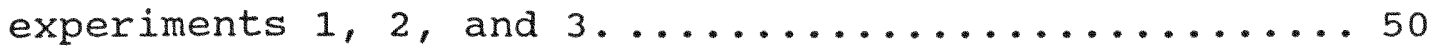
10. Effects of $\mathrm{P}$ on glucosidase activity for experiments

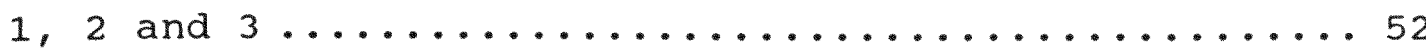


11. Effects of $\mathrm{P}$ on sulfatase activity for experiments

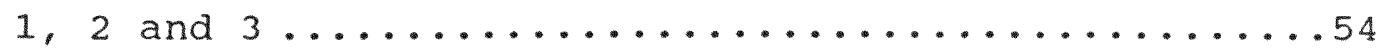

12. Effects of $P$ on glucoseaminidase activity for

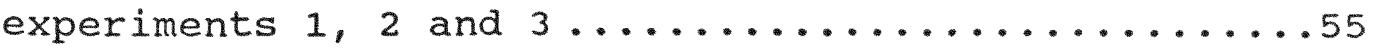

13. Effects of $\mathrm{P}$ on microbial biomass for experiments

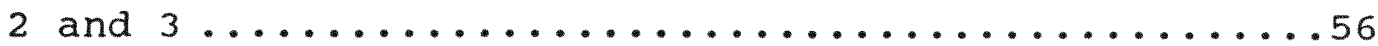




\subsection{INTRODUCTION}

The Everglades is believed to have evolved as a phosphorus limited, oligotrophic, wetland (Davis, 1994). In recent years, loading of agricultural drainage water into the Everglades water Conservation areas (WCA) has resulted in nutrient enrichment of soil and vegetation in many areas (DeBusk et al., 1994). Walker (1991) reported increases in total phosphorus concentrations of $4-21 \%$ per year at 8 of 9 inflow sites to Everglades National Park. Several ecological changes have been attributed to the nutrient enrichment in the Everglades ecosystem: 1) conversion of sawgrass (Cladium jamaicense) stands to areas dominated by cattail (Typha spp.); 2) replacement of the oligotrophic periphyton mat communities by pollution tolerant filamentous algae; 3) lower dissolved-oxygen concentrations in eutrophic sites; and 4) decreased colony counts of facultative bacteria and fungi that colonize leaf litter at eutrophic sites (Davis, 1994).

Many wetland soils are typically characterized by high organic matter accumulation compared to soils from adjacent upland ecosystems. Organic carbon (C) accumulation in wetlands is due to a high rate of primary productivity and a reduced rate of decomposition under anaerobiosis (Reddy and D'Angelo, 1994). Factors that influence the rate of decomposition include the chemical and physical composition of the organic substrate, the availability of electron 
acceptors, and environmental factors such as temperature, pH, moisture, and nutrient availability (Swift et al., 1979; Reddy and D'Angelo, 1994). In a study conducted to determine the influence of nutrient enrichment on turnover of detrital pools, phosphorus and lignocellulose content in peat and plant litter explained approximately $90 \%$ of the variability in potential organic $\mathrm{C}$ mineralization (DeBusk and Reddy, 1997). Increased soil phosphorus level was implicated in determining whether aerobic or anaerobic microbial metabolism will predominate in peat soils of the Florida Everglades (Amador and Jones, 1995). Changes to the microbial communities will alter carbon and nutrient cycling and may effect higher trophic level communities, therefore, further studies are needed to characterize the effects of increased phosphorus (P) levels in order to search for measures that might mitigate these problems.

Mercury $(\mathrm{Hg})$ is another contaminant of concern in the Florida Everglades and its biogeochemistry has been closely studied due to its great toxic potential. Possible causes of the mercury problem in south Florida may be related to: (1) increased atmospheric deposition of $\mathrm{Hg}$ derived from anthropogenic sources such as urban emissions and burning of crop material (Sengar et al., 1989); (2) increased $\mathrm{Hg}$ in agricultural runoff due to enhanced oxidation of peat soil in agricultural land (Delfino, et al., 1993), and (3) altered microbial processes caused by eutrophication and 
perturbations of the natural hydroperiod (Amador and Jones, 1993).

In wetlands characterized by organic soils, $\mathrm{Hg}$ is strongly bound to organic matter, making it purportedly unavailable for uptake by the aquatic food chain (zillioux et al., 1993). However, concentrations of methylmercury (MeHg) in largemouth bass from the Everglades are the highest in the state of Florida ( $>3 \mathrm{ppm}$ ) (Hand and Friedman, 1990), and are greater than any concentration of total $\mathrm{Hg}$ in fish reported in the National Contaminant Biomonitoring Program of 1976-1984 (Schmitt and Brumbaugh, 1990). Also, Hg accumulation through the food web may be causing chronic health problems, and reducing the breeding success of wading birds (Frederick and Spalding, 1994) and the viability of the endangered Florida Panther (Roelke et al., 1991). Consequently, a widespread concern has arisen that $\mathrm{Hg}$ contamination in the Everglades poses a serious hazard to the health of the public and the ecosystem.

\subsection{OBJECTIVE}

Previous research has suggested that agricultural practices in the Everglades Agricultural Area (EAA) have altered the biogeochemical cycle of phosphorus by increasing runoff. This may have produced a shift in the microbial communities from aerobically dominated to anaerobically dominated processes in some areas of the Everglades. A 
study conducted on phosphorus geochemistry in sediments of Lake Okeechobee, Florida suggested that, iron phosphate precipitation controls phosphorus behavior under oxidizing conditions, while calcium phosphate mineral precipitation governs phosphorus solubility under reducing conditions. Therefore, under low dissolved oxygen conditions, large fluxes of phosphorus from the sediment could occur due to the solubilization of ferric phosphate minerals (Moore and Reddy, 1994). This suggests that agricultural runoff not only adds nutrients directly to the Everglades but may also increase the cycling of stored phosphorus. Amador and Jones (1995) reported that carbon mineralization was significantly increased in soils high in total phosphorus (1.473 $\mathrm{gP} \mathrm{kg}^{-1}$ ), compared to those low in total phosphorus $\left(0.231 \mathrm{gP}^{\mathrm{kg}^{-1}}\right)$. Additionally their results indicated that increased $\mathrm{p}$ levels may cause a shift in carbon metabolism from aerobically dominated to anaerobically dominated processes.

The primary objective of this study was to simulate the effects of nutrient-rich, agricultural runoff from the EAA on anaerobic microbial activity in peat soils from the Everglades. Specifically, the study was designed to evaluate the differences in microbial carbon metabolism in peat soils dosed with increasing concentrations of phosphorus and amended with glucose as a labile organic carbon source. Differences were evidenced as shifts in microbial communities from aerobically dominated to 
anaerobically dominated systems. This shift was determined by the measurement of redox potential (Eh), carbon dioxide $\left(\mathrm{CO}_{2}\right)$ and methane $\left(\mathrm{CH}_{4}\right)$ evolution, enzyme activity, and bacterial density. Aerobic soils generally have Eh values between 400 and $600 \mathrm{mV}$ while anaerobic soils generally have Eh values between 100 and $-400 \mathrm{mV}$. Therefore, Eh is a good indicator for quantitatively distinguishing aerobic versus anaerobic soils (Rowell, 1981).

Altered biogeochemical cycling may also have caused the cycle of mercury to be altered, perhaps resulting in increased mercury methylation in the Everglades ecosystem. A second part of this study was to determine the influence of increased phosphorus concentrations along with a labile organic carbon source on anaerobic microbial populations that might be linked to mercury methylation. The conditions in the runoff-impacted areas that may encourage MeHg accumulation include enhanced microbial activity, changes in the chemical characteristics and composition (fulvic/humic ratios) of organic matter, reduced soil redox potentials, increased rates of sulfate reduction, and increased aqueous concentrations of inorganic mercury in surface and pore water. In this study, evolution of $\mathrm{CO}_{2}$ and $\mathrm{CH}_{4}$ were measured. Measurements of $\mathrm{CO}_{2}$ and $\mathrm{CH}_{4}$ emissions allows for the assessment of net carbon mineralization and to evaluate the relative importance of aerobic and anaerobic routes of carbon metabolism in these soils (Amador and Jones, 1995). 
Enzyme assays have become useful techniques for monitoring microbial activity and uncovering the mechanisms that underlie microbial processes (Sinsabaugh, 1992). Enzyme activities were determined on the soil from each of the columns via an assay using the fluorescent model substrate 4-methylumbelliferone (MUF) (Hoppe 1993; sinsabaugh et al. 1997). Samples were analyzed for four different extracellular enzymes. Three of the enzymes are involved in macronutrient cycles. The extracellular enzymes analyzed were those that recover phosphorus, nitrogen, and sulfur from organic substrates. The fourth extracellular enzyme analyzed is one which is involved in lignocellulose degradation. Bacterial densities in the soil from each of the treated columns was determined by a flourometric assay using the double-stranded DNA stain Pico-Green (PG) (Molecular Probes). Increased microbial biomass production as a result of $\mathrm{P}$ may indicate a release from $\mathrm{P}$ limitation.

\subsection{REVIEW OF THE LITERATURE}

\subsection{Characteristics of the Everglades Ecosystem}

The Florida Everglades represents the largest (500,000 ha) freshwater sub-tropical peatland in North America. The Everglades originally evolved under rainfall driven phosphorus-limiting conditions, (Davis, 1994), and surface water drained southward from Lake okeechobee through this slightly alkaline peatland as sheetflow (Davis and 
Ogden, 1994). The ecosystem is comprised of sawgrass marshes, open water sloughs, wet prairies and tree island communities (Loveless, 1959) which serve as habitats for a large number of species including several threatened and endangered species: wood storks, snail kites, bald eagles and Florida panthers (Davis and Ogden, 1994).

\subsection{Anaerobic Microbial Metabolism}

Most wetland environments are characterized by widespread anoxia, thus the importance of anaerobic metabolism in organic matter turnover is greatly increased in wetlands verse terrestrial ecosystems (Reddy and D'Angelo, 1994). The predominate type of anaerobic respiration in wetlands depends on the relative availability of alternate electron acceptors such as $\mathrm{NO}_{3}^{-}, \mathrm{SO}_{4}{ }^{2-}, \mathrm{CO}_{2}, \mathrm{Mn}^{4+}, \mathrm{Fe}_{3}^{+}$, and $\mathrm{Mn}_{4}{ }^{+}$. Utilization of these electron acceptors by heterotrophic microflora follows a thermodynamically predictable sequence, but also depends on the availability of the compounds (Fenchel and Blackburn, 1979; Reddy and D'Angelo, 1994). Microbial respiration in freshwater wetlands is frequently limited by electron acceptor availability, rather than $C$ availability as in terrestrial ecosystems. In the complete absence of electron acceptors, methanogenesis is the major metabolic pathway in anaerobic wetland soils (Westermann, 1993). Microbial respiration in estuarine ecosystems such as saltmarshes and mangrove swamps is dominated by sulfate 
reducing bacteria, due to the high concentration of sulfate (Widdel, 1988). Sulfate reducers and methanogens utilize most of the same metabolic by-products of fermenting bacteria, which do not require an external source of electron acceptors (Oremland, 1988; Widdel, 1988). Generally sulfate reducing bacteria have the ability to outcompete methanogenic bacteria for these substrates in the presence of sulfate (Fenchel and Blackburn, 1979). Where the availability of suitable $C$ substrate is sufficiently high, methanogenesis and sulfate reduction both may contribute significantly to soil respiration in high sulfate soils (Oremland, 1988).

\subsection{Effects of Eutrophication}

Large areas of the northern and eastern Everglades have been drained for agricultural and urban land uses. The central Everglades is fragmented into several units where the hydrology is regulated by pumps and canals (Everglades Agricultural Area [EAA], Water Conservation Areas [WCA-1, WCA-2 and WCA-3] and Everglades National Park [ENP]). A map of the Florida Everglades is provided as Figure 1. Since the 1960 's, nutrient-enriched agricultural drainage from the EAA has been pumped into the WCA's. WCA-1 and WCA-2 in particular have received the bulk of the runoff, but all three WCA's and ENP have suffered severe hydrological alterations (primarily through drainage and artificial 
discuption of the hydroperiod). The mean annual supply of $P$ to the WCA's appears to have increased nearly three-fold, from levels of approximately 129 tonnes under predrainage conditions to approximately 376 tonnes in the 1980 s (Davis, 1994). Nutrient additions to the Everglades have contributed to shifts in native macrophyte communities from sawgrass to cattail in some places (Davis 1994), and a eutrophication gradient characterized by high concentrations of $\mathrm{P}$ in surface water and increased $\mathrm{P}$ accumulation in the soil has developed in the northern part of WCA-2A (e.g. P concentration in the enriched and unenriched soils are 0.54 to 1.14 and 0.11 to $0.25 \mathrm{~g} \mathrm{P} \mathrm{m}^{-2} \mathrm{yr}^{-1}$ soil respectively) (Koch and Reddy, 1992; Reddy, et al., 1993). Eutrophication has also resulted in :

1. enhanced soil microbial activity (Amador and Jones, 1993);

2. increased accumulation rates for nutrients and organic matter in soil (Reddy et al.,1993);

3. a 5-10\% increase in labile soil organic matter content and enhanced rates of organic matter composition in eutrophic soils compared to noneutrophic soils (Qualls and Richardson, 1995);

4. increased degree of soil anaerobiosis (Davis, 1994; Amador and Jones, 1995);

5. increased concentrations of fulvic acid in the water column (Qualls and Richardson, 1995); and 


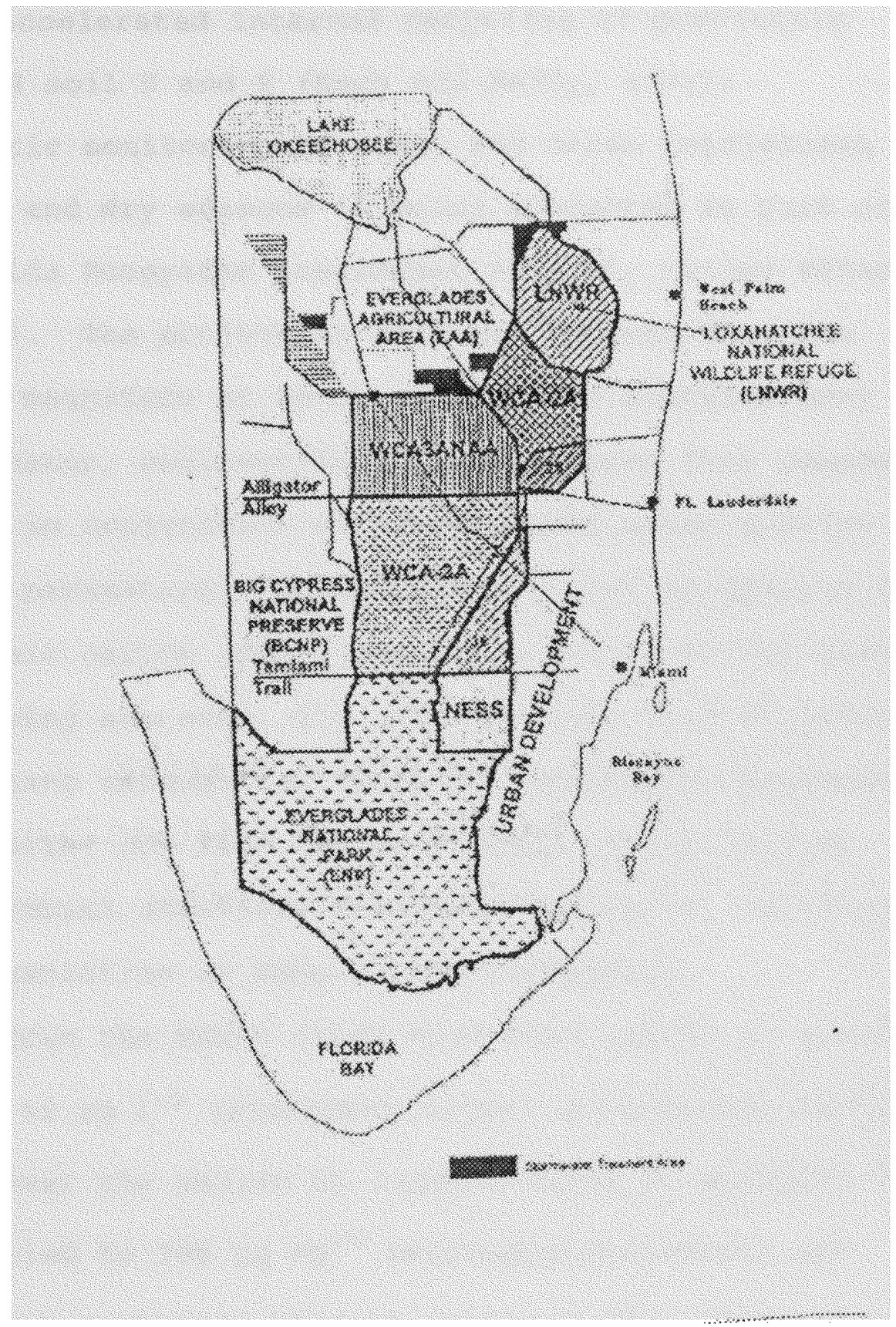

Figure 1: Map of the Florida Everglades 
6. accelerated internal recycling of previously stored soil N and P (Koch and Reddy, 1992).

synoptic monitoring of canal and marsh populations during wet and dry seasons is being conducted as part of the South Florida Ecosystem Assessment Project, called REMAP (EPA, 1998). The project is designed to determine the extent and magnitude of total mercury and methylmercury (MeHg) in water, sediment/soil, and mosquito fish (Gambusia holbrooki) in conjunction with associated water quality and hydrologic parameters. The effects of total phosphorus (TP), total organic carbon (TOC), and total ionic sulfate $\left(\mathrm{TSO}_{4}\right)$ are also being assessed. The data indicate that TP affects emergent plant communities, floating periphyton presence, aquatic habitat and food web complexity, which in turn affect microbial activity, mercury methylation, biodilution and bioaccumulation of MeHg in the Everglades.

Data from the REMAP study show that median TP declined from 16 to $12 \mu \mathrm{g} \mathrm{L}^{-1}$ (microgram/liter) progressing north to south, however the median $\mathrm{Hg}$ concentration in mosquito fish nearly doubled to $208 \mu \mathrm{kg}^{-1}$ (microgram/kilogram) and remained high southward through northern ENP. However as TP continued to decline (median $=8.6 \mu \mathrm{g} \mathrm{L} \mathrm{L}^{-1}$ ) the $\mathrm{Hg}$ concentration in mosquitofish declined to $156 \mu \mathrm{g} \mathrm{kg}^{-1}$ in the southern portion of ENP. Median MeHg concentrations in water declined north to south in both canal (i.e., 0.3 to 
$0.06 \mathrm{ng} / \mathrm{L}$ ) and marsh (i.e., 0.54 to $0.15 \mathrm{ng} / \mathrm{L}$ ) habitats indicating higher methylation occurred in the marsh. The marsh median mosquitofish bioaccumulation factor (BAF) for $\mathrm{Hg}$ increased from $0.6 \times 10^{5}$ in the north to $8.5 \times 10^{5}$ in the southern portion of ENP indicating an increasing bioaccumulation efficiency in the food chain from north to south. Total mercury in periphyton, great egrets, and mosquitofish also was spatially correlated with a Hg "hot spot" between Alligator Alley and Tamiami Trail. The stimulatory effects of $\mathrm{TP}$ on the plant communities and the methylating microbes appears to be a key component in mercury contamination in the Everglades. Other studies have suggested that enhanced organic matter production resulting from eutrophic conditions may affect methylmercury production by providing more organic substrates for direct utilization by methylating microbes (Bodaly, et al., 1984) and by creating more anoxic conditions (Jackson, 1988). Thus, eutrophication-induced changes in the Everglades may create a favorable environment for faunal bioaccumulation of MeHg via the stimulation of microbial methylation.

\subsection{Transformations of Mercury and their Relevance to}

\section{Methylmercury (MeHg)}

Transformations of mercury in the environment are a key issue in any mercury contamination problem. The input of mercury from natural and anthropogenic sources is mostly in 
the inorganic form, but the mercury found in fish is almost exclusively in the methylated form (Grieb et al., 1990). The amount of MeHg that is available for bioaccumulation is a function of the rate of mercury methylation relative to the rate of $\mathrm{MeHg}$ demethylation. Processes such as reduction, volatilization, adsorption, and precipitation are also important as they regulate the concentration of ionic mercury, the substrate for methylation. Both biochemical and abiotic mechanisms of mercury methylation have been demonstrated, but it is unclear as to whether the laboratory findings are applicable to field settings, and which mechanisms predominate under natural conditions.

sulfate reducing bacteria (SRB) play a critical role in the cycling of carbon to marine and estuarine sediments by using the partially degraded products of fermentation as a carbon source and sulfate as an electron acceptor (Widdel, 1988). In freshwater sediments where sulfate is not abundant, final decomposition is mostly performed by methanogenic bacteria (Oremland, 1988). However, sulfate reduction does occur in freshwater sediments, and increased sulfate concentrations in runoff may be adequate to promote methylation by SRB. Koch-Rose et al., 1994 observed millimolar levels of sulfate concentrations in the interstitial water of eutrophied soils in the Everglades. Based on experiments with pure cultures, methanogens were proposed to be the primary methylators of mercury in 
the environment (Wood, 1974). The role of sulfate reducing bacteria (SRB) in methylation of mercury in estuarine (Compeau and Bartha, 1985) and freshwater (Gilmour et al., 1992) sediments was discovered when studies were performed using specific inhibitors of methanogenesis and sulfate reduction. These findings are supported by the similarity between profiles of mercury methylation and sulfate reduction in sediment cores (Gilmour et al., 1992). In Desulfovibrio desulfuricans, the transfer of a methyl group from methylcobalamine $\mathrm{B} 12$ to $\mathrm{Hg}(\mathrm{II})$ is known to be enzymatically catalyzed (Choi et al., 1994).

A well-documented pathway for the biotic degradation of methylmercury is the organomercurial lyase-mediated protonolytic attack on the $\mathrm{C}-\mathrm{Hg}$ bond, producing $\mathrm{CH}_{4}$ and $\mathrm{Hg}(I I)$. Organomercurial lyase is an inducible enzyme requiring the presence of ionic- or organomercury (Silver and Walderhaug, 1992). Alternatively oremland et al. (1991) observed demethylation in estuarine and freshwater sediments and found that an oxidative demethylation mechanism (producing ${ }^{14} \mathrm{CO}_{2}$ rather than ${ }^{14} \mathrm{CH}_{4}$ ) predominated in estuarine sediments under anaerobic conditions, while the more familiar organomercurial lyase reaction (producing ${ }^{14} \mathrm{CH}_{4}$ ) was most important under aerobic conditions. The use of molybdate had no effect on demethylation under either circumstance, indicating that SRB are not of importance in the demethylation reaction in estuarine sediment. The 
situation in freshwater sediments is more complex. The organomercurial lyase reaction (production of ${ }^{14} \mathrm{CH}_{4}$ ) was partially halted by inhibitors specific for methanogens, but the same inhibitor had no effect on oxidative demethylation. Also the organomercurial lyase demethylation occurred to equal extents under aerobic and anaerobic conditions, but oxidative demethylation was five times greater in anaerobic slurries. The nature of oxidative demethylation and its significance in the biogeochemical cycling of mercury in the Everglades needs to be investigated, as the amount of methylmercury available for biotic uptake is determined by the balance between methylation and demethylation reactions.

\subsection{HYPOTHESIS}

Previous work on nutrient enrichment and mercury methylation suggests that alterations of the natural hydroperiod, together with farm runoff from agricultural activities in the EAA, have altered the natural biogeochemical cycle of phosphorus and mercury, and to a lesser extent nitrogen, resulting in reducing conditions due to increased anaerobic microbial activity and perhaps mercury methylation in parts of the Everglades ecosystem. The central hypothesis is that the flow of nutrient enriched runoff into the Everglades ecosystem contributes to conditions that lead to increased anaerobic microbial activity and the accumulation of methylmercury in the 
system. The export of nutrients from the EAA results in increased microbial carbon metabolism. This increase in microbial carbon metabolism leads to the utilization of available $\mathrm{O}_{2}$ and results in a shift to anaerobic microbial communities that utilize fermentation and alternate electron acceptors, such as $\mathrm{NO}_{3}{ }^{-}, \mathrm{SO}_{4}{ }^{-}, \mathrm{CO}_{2}, \mathrm{Fe}_{3}{ }^{+}$, and $\mathrm{Mn}_{4}{ }^{+}$.

Anaerobic conditions, sulfate reducing bacteria, methanogens, and methylcobalamin (a methylated vitamin $B_{12}$ derivative which acts as a cofactor) mediated reactions have been implicated in the methylation of mercury (Choi and Bartha 1993, Choi et al., 1994, Compeau and Bartha, 1985, Gilmour et al. 1992, and Wood, 1974). Additionally, the export of dissolved organic carbon from the EAA is accompanied by the export of organically-bound mercury, and anaerobic conditions fostered by the agricultural runoff favor mercury methylation over demethylation.

The effects of phosphorus additions on anaerobic microbial activity in the Everglades was explored through a combination of mensurative and experimental methods. Soil was collected from the Shark River Slough area of Everglades National Park (Figure 2). Soil columns (Figure 3) maintained in the lab were used to assess the effects of phosphorus additions along with a carbon source on anaerobic microbial activity. A preliminary study was conducted in which phosphorus alone was added at concentrations of $0,1,10$, 100, and $1000 \mu \mathrm{M}$ to the soil columns. There was no 
significant change observed of redox potential between the control and the treatments or among the treatments (Table 1 and Table 2). When glucose was added in addition to phosphorus a notable decrease in redox potential was observed between the control and the treatments but not among the treatments (Figure 3 ). The addition of $\mathrm{PO}_{4}{ }^{-3}$ to each of the treatment columns was then reduced to $0,0.5,1$, and $5 \mu \mathrm{M} \mathrm{PO}{ }^{-3}$. The soil used in the first experiment with these $\mathrm{PO}_{4}^{-3}$ concentrations had not been allowed to stabilize prior to being placed in the columns. This resulted in the control and the treatment columns becoming reduced with Eh values indicative of anoxic or reducing conditions followed by an increase in redox potential with Eh values indicative of aerobic conditions (Figure 4). The current study was conducted using the $0,0.5,1$, and $5 \mu \mathrm{M} \mathrm{PO}_{4}{ }^{-3}$ and allowing the soil to stabilize for at least one month prior to conducting the experiment. The soil was aged to allow for the breakdown of any labile organic matter present in the soil which may have caused the fluctuation in the redox potential discussed above.

Homogenized soil slurries were shown to result in a significant decrease in variability within treatments and to have no statistically significant effect on long-term rates of respiration in Everglades peat soil (Amador and Jones, 1993). The following are the hypothesis for the current study: 


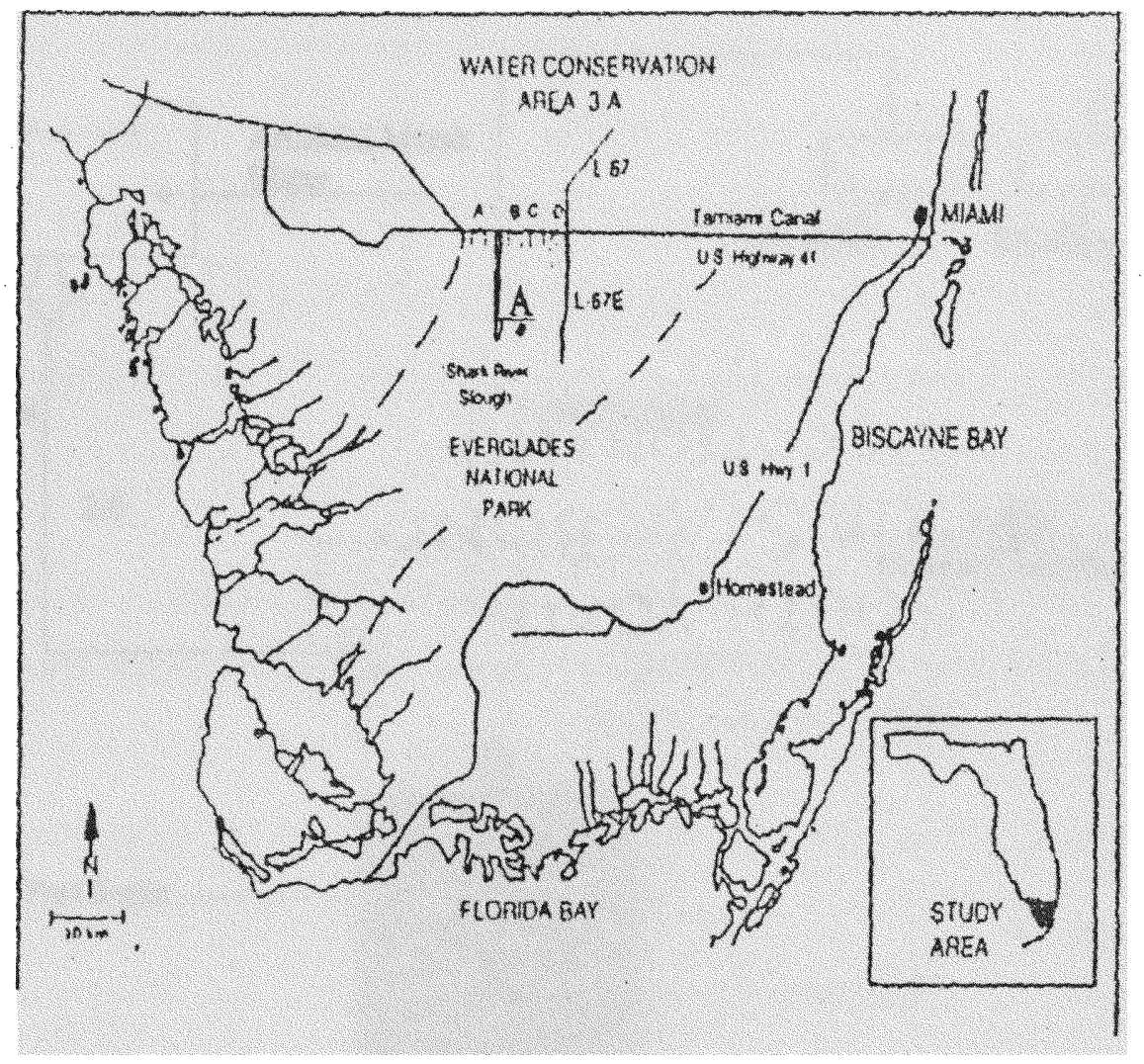

Eigure 2: Site location map. The letter $A$ indicates the approximate soil collection area. 
Eigure 3: Soil Column

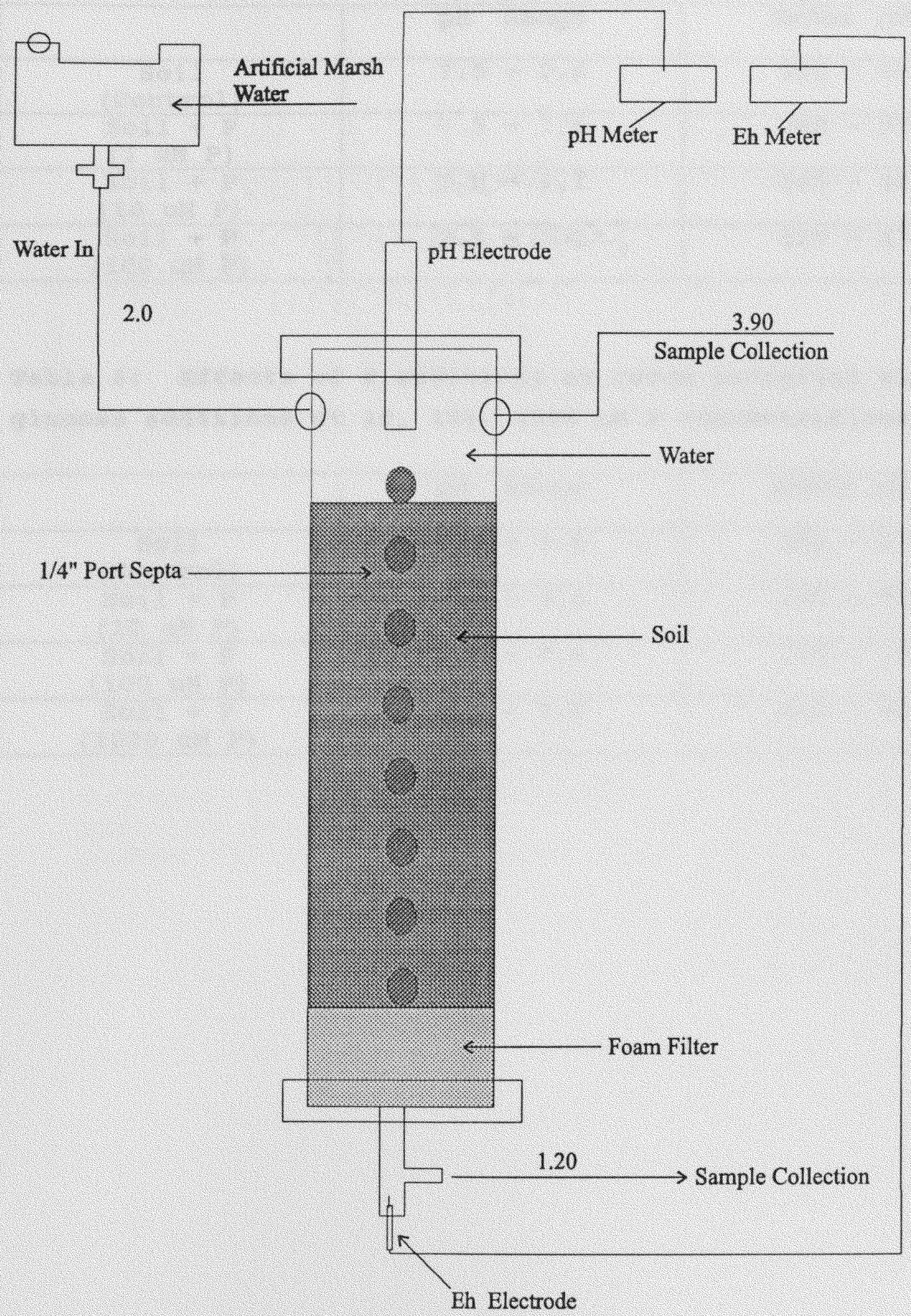


Table 1: Effects of $P$ additions on redox potential with no glucose addition at 1,10 and $100 \mathrm{uM}$ P concentrations.

\begin{tabular}{|c|c|c|}
\hline & $\mathrm{pH}$ Range & Redox (mV) \\
\hline $\begin{array}{c}\text { Soil } \\
(\text { Control) }\end{array}$ & $7.5-7.6$ & $350-370$ \\
\hline $\begin{array}{c}\text { Soil }(1 \mathrm{P} \\
(1 \mathrm{uM})\end{array}$ & $7.5-7.6$ & $350-370$ \\
\hline $\begin{array}{c}\text { Soil P } \\
(10 \mathrm{uM})\end{array}$ & $7.5-7.7$ & $360-380$ \\
\hline $\begin{array}{c}\text { Soil P } \\
(100 \mathrm{uMP})\end{array}$ & $7.5-7.8$ & $420-470$ \\
\hline
\end{tabular}

Table 2: Effects of $P$ additions on redox potential with no glucose additions at 10, 100, 1000 uM P concentrations.

\begin{tabular}{|c|c|c|}
\hline & pH Range & Redox (mV) \\
\hline $\begin{array}{c}\text { Soil } \\
\text { (Control) }\end{array}$ & $7.5-7.6$ & $350-370$ \\
\hline $\begin{array}{c}\text { Soil }+\mathrm{P} \\
(10 \text { uM P) }\end{array}$ & $7.4-7.6$ & $350-370$ \\
\hline $\begin{array}{c}\text { Soil P P } \\
(100 \text { uM P) }\end{array}$ & $7.6-7.9$ & $370-390$ \\
\hline $\begin{array}{c}\text { Soil + P } \\
(1000 \text { uM P) }\end{array}$ & $7.6-7.8$ & $410-430$ \\
\hline
\end{tabular}




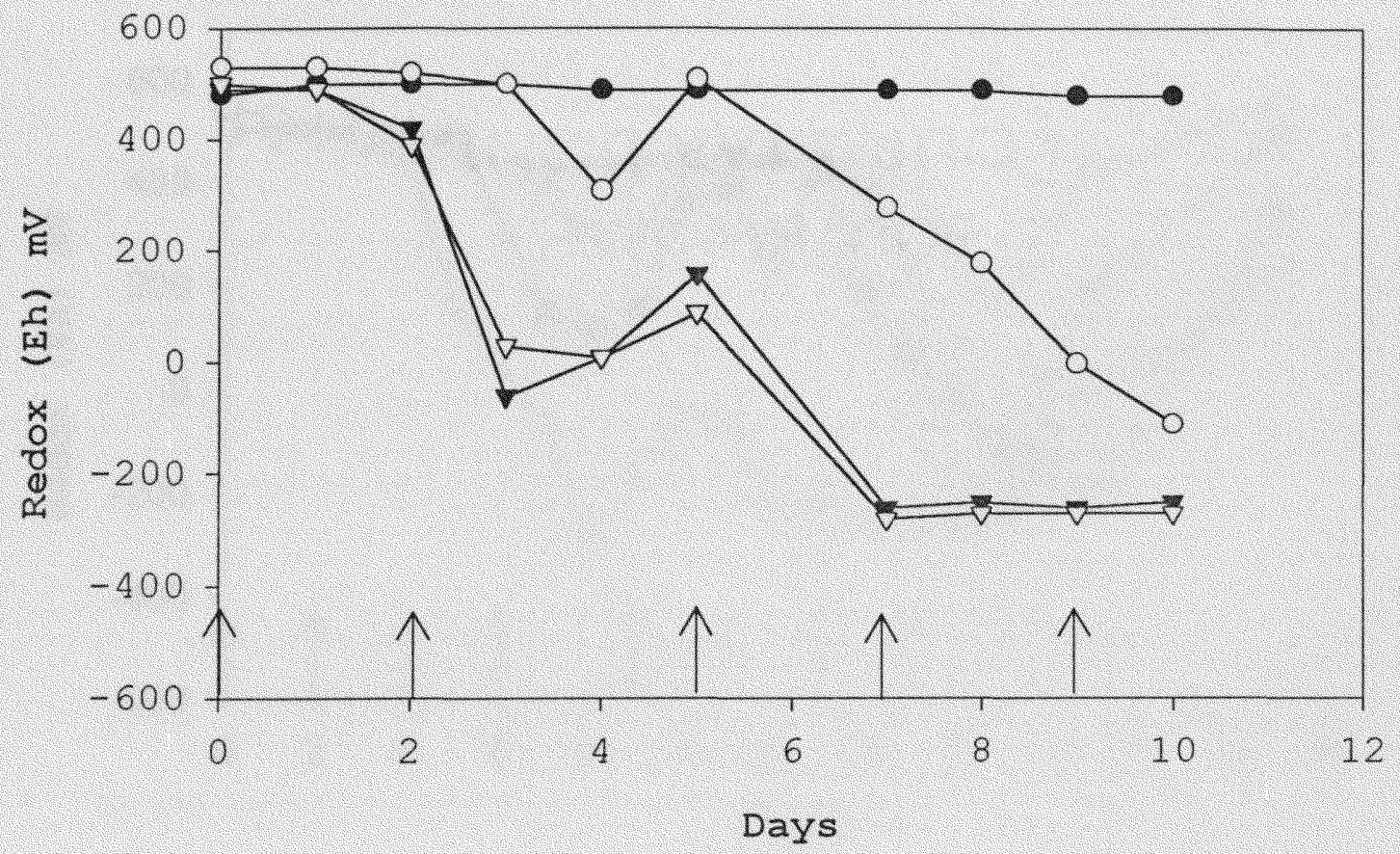

Figure 3: Effects of $\mathrm{P}$ on redox potential for the first experiment conducted which used high $\mathrm{P}$ level additions and added glucose however the soil was not aged.

- Control

$-\infty$ 1. OuM P

$\longrightarrow$ 5.0uM P

$\longrightarrow$ 10.0uM P

$\uparrow \begin{aligned} & \text { Glucose } \\ & \text { Addition }\end{aligned}$ 


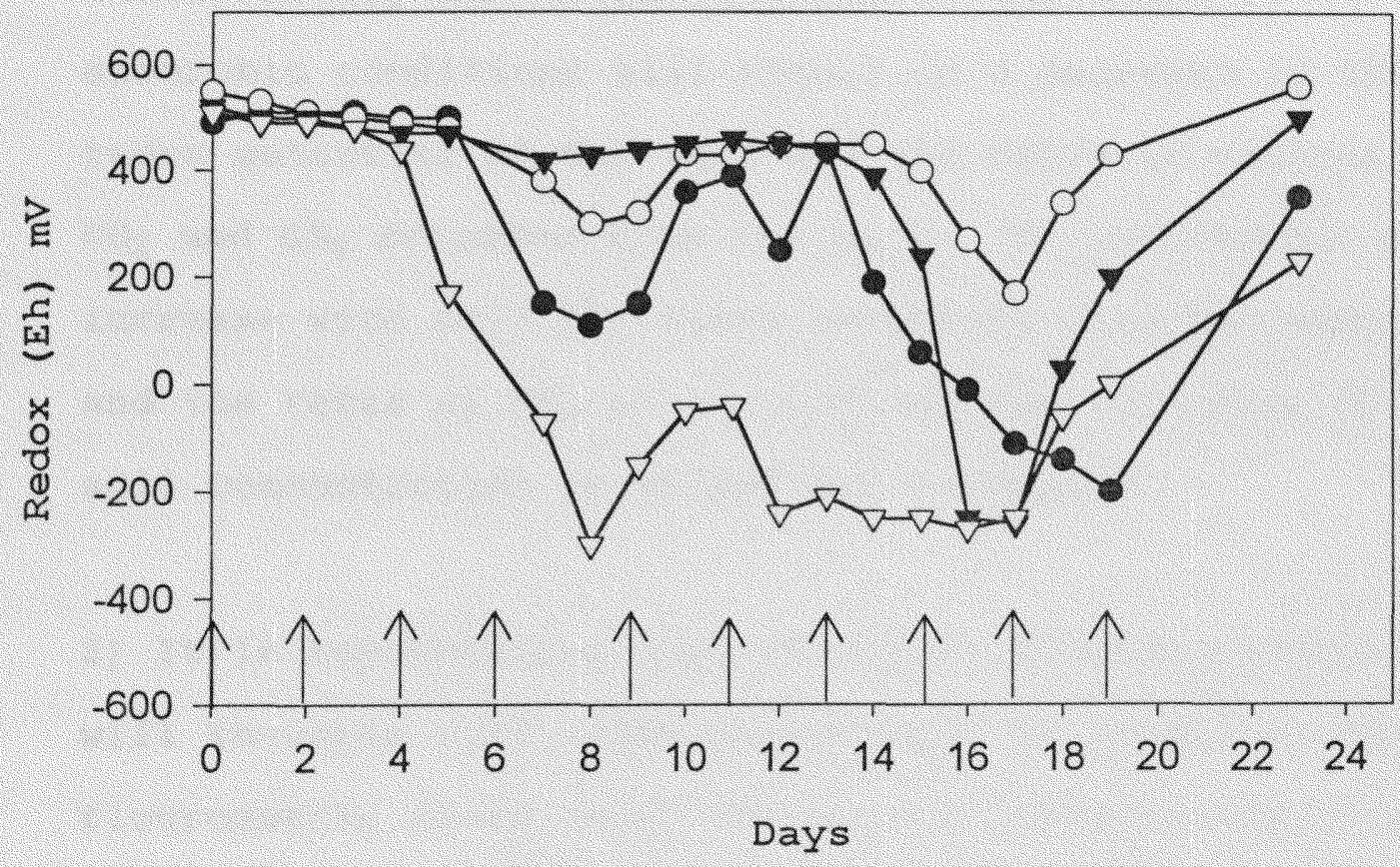

Figure 4: Effects of $P$ on redox potential for the second experiment conducted with glucose addition prior to aging the soil.

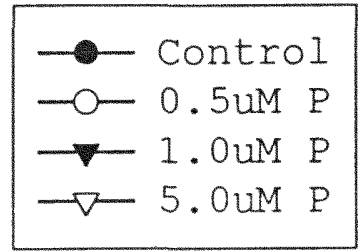

$\uparrow \begin{aligned} & \text { Glucose } \\ & \text { Addition }\end{aligned}$ 
1) Phosphorus additions, along with glucose, are hypothesized to result in shifts in the microbial communities from aerobically dominated processes to anaerobically dominated processes. The shift to anaerobic conditions will result in a decrease in the redox potential of the soil and the ratio of gaseous $\mathrm{CO}_{2}$ and $\mathrm{CH}_{4}$ released from the soil. $\mathrm{CO}_{2}$ production will increase with soil TP. Redox potential will decrease and the ratio of $\mathrm{CH}_{4}$ to $\mathrm{CO}_{2}$ evolved will increase as soil concentration of phosphorus increases.

2) It is hypothesized that microbial biomass production will increase with added phosphorus, as evidenced by a flourometric assay using the double-stranded DNA stain PicoGreen (PG) (Molecular Probes) as modified from Tranvik (1997). This increase in bacterial density will also signal a release from $\mathrm{P}$ limitation (Jones et al., 1995).

3) As soil concentrations of TP increase alkaline phosphatase activity (APA) will decline and carbon, nitrogen, and sulfur acquiring enzyme activities will increase. The changes in microbial exoenzyme production will be measured using flourescently labeled substrates after a method modified from Hoppe (1993). 


\subsection{METHODOLOGY}

5.1 Field samples and column preparation

Soil was collected from the shark River Slough area of Everglades National Park in close proximity to an on-going research project (Jones et al., 1995). This is a pristine area uninfluenced by agricultural runoff. The soil characteristics are given in Table 3. Between five and ten grab samples of the top $10 \mathrm{~cm}$ of soil were collected in plastic containers prior to each experiment and transported to the lab immediately. Samples brought from the field were spread on a plastic pan and mixed after removing white roots, rocks, snail shells, etc. The soil was then returned to the plastic containers and placed in an incubator at $28^{\circ} \mathrm{C}$ for approximately one month. The soil was aged to allow for the breakdown of any labile organic matter present in the soil leaving only the recalcitrant peat soil to use in the treatment columns. Homogenized soil slurries were shown to result in a significant decrease in variability within treatments and to have no statistically significant effect on long-term rates of respiration in Everglades peat soil (Amador and Jones, 1993).

Soil columns were prepared by placing 300 grams of the stabilized marsh soil in each of the columns. The columns simulate overland flow and infiltration. A $45 \mathrm{~mm}$ thick polypropylene foam plug was placed at the bottom of the column to prevent loss of soil. The foam plugs were shown 
Table 3: Chemical properties of soils used in this study

\begin{tabular}{|c|c|c|c|c|c|c|}
\hline & $\mathrm{OM}:$ & c. & N & P. & $\mathrm{C} \times \mathrm{N}$ & c.P \\
\hline Exp. 1 & 89.4 & 505.03 & 36.4 & 0.152 & 13.81 & 3322.57 \\
\hline Exp. 2 & 89.4 & 501.30 & 37.4 & 0.340 & 13.40 & 1474.41 \\
\hline Exp. & 89.4 & 474.45 & 34.6 & 0.304 & 13.71 & 1560.69 \\
\hline
\end{tabular}

Units for $C, N$, and $P$ are $g \mathrm{~kg}^{-1} \mathrm{dw}$ soil 
not to absorb $\mathrm{PO}_{4}$ from a $1.0 \mu \mathrm{M} \mathrm{PO}_{4}$ solution (Amador et al. 1992). The soil columns were washed for three days with buffered salt solution, artificial marsh water ( AMW, pH 7.5) (Amador and Jones 1993) at a flow rate of $30 \mathrm{ml} \mathrm{h}^{-1}$ to equilibrate the $\mathrm{pH}$ of the effluent and to allow the soil time to settle. The buffered salts solution has the same $\mathrm{pH}$ and contains the same concentration of major inorganic ions as the marsh water originally overlying the soil. The buffered salts solution contains the following (milligrams per liter): $\mathrm{NaHCO}_{3}, 23.0 ; \mathrm{KCl}, 0.6 ; \mathrm{MgCl}_{2} \cdot 6 \mathrm{H}_{2} \mathrm{O}, 11.0$; and $\mathrm{CaCl}_{2} \cdot 2 \mathrm{H}_{2} \mathrm{O}, 46.0$ (Jones and Amador, 1992). The buffered salt solution ( $\mathrm{pH} 7.5)$ containing a known concentration of phosphorus was then passed through the columns. Glucose was added as an aqueous solution $\left(1 \mathrm{~g} \mathrm{ml}^{-1}\right)$ at $0.5 \mathrm{ml}$ every other day to each of the soil columns. The soil columns were connected to $\mathrm{pH}$ and redox meters, which constantly collected measurements throughout the experiment. Redox was measured with platinum redox electrodes at the bottom of each soil column. Redox potential values were corrected by adding the potential of the standard $\mathrm{H}$ electrode, $200 \mathrm{mV}$, to the $\mathrm{mV}$ reading of the $\mathrm{AgAgCl}_{2}$ reference electrode.

\subsection{Experimental Manipulations}

Mineralization of the peat soil was determined by amending the soil slurry samples with individual compounds and measuring the anaerobic microbial activity by monitoring 
the decreasing redox potential. An experiment was conducted to measure the level of anaerobic decomposition in the soil columns amended with increasing phosphorus concentrations in conjunction with glucose, a labile organic carbon source. Phosphorus was added as $\mathrm{NaH}_{2} \mathrm{PO}_{4}$ to the buffered salts solution. The $\mathrm{pH}$ of the salts solution was adjusted to 7.5 before being passed through the soil columns. The soil columns were set up as follows: 1) a control column treated with the buffered salts; 2) a low Pcolumn, treated with $\mathrm{P}$ at a concentration of $0.5 \mu \mathrm{M}(15 \mu \mathrm{g}$ $\left.\mathrm{L}^{-1}\right)$; 3) an intermediate-P column treated with $\mathrm{P}$ at a concentration of $1.0 \mu \mathrm{M}\left(30 \mu \mathrm{g} \mathrm{L}^{-1}\right)$; and 4) a high-P column treated with $\mathrm{P}$ at a concentration of $5.0 \mu \mathrm{M}\left(150 \mu \mathrm{g} \mathrm{L}^{-1}\right)$. Glucose was added as an aqueous solution ( $\left.1 \mathrm{~g} \mathrm{ml}^{-1}\right)$ at $0.5 \mathrm{ml}$ every other day to each of the soil columns. After the columns were dosed with phosphorus, a soil core was taken from each of the columns. The soil core was sliced at $2 \mathrm{~cm}$ depth increments. Approximately one half gram from each soil sample (increment) was analyzed for $\mathrm{CO}_{2}$ and $\mathrm{CH}_{4}$ evolution. The remaining soil in each of the columns was homogenized and used to analyze enzyme activity and bacterial density. Enzyme activities were determined on the soil from each of the columns via an assay using the fluorescent model substrate 4-methylumbelliferone (MUF) (Hoppe 1993; Sinsabaugh et al. 1997). Four enzyme substrates were used. They are 4-methylumbelliferyl- 
phosphate, MUF- $\beta-1-4-$ glucoside, MUF-N-Acetyl- $\beta-D-$

glucosaminidine, and MUF-Sulfate. Bacterial densities in the soil from each of the treated columns was determined by a flourometric assay using the double-stranded DNA stain Pico-Green (PG) (Molecular Probes Product Sheet).

\subsection{ANALYTICAL METHODS}

\subsection{Gas Analysis}

A soil core was taken from each of the treatment columns. The soil core was sliced at $2 \mathrm{~cm}$ depth increments. Soil samples $(0.5-1 \mathrm{~g})$, taken in triplicate, from each increment were placed in $20 \mathrm{ml}$ gas chromatograph sampling vials. Those vials were then capped with rubber serum stoppers, sealed, and the headspace was replaced with $\mathrm{N}_{2}$. Samples were then incubated in the dark at $25^{\circ} \mathrm{C}$ until withdrawing a $2.0 \mathrm{ml}$ gas sample from the headspace by gas displacement at 72 hours with an automatic headspace (model 19395A; Hewlett Packard, Palo Alto, CA). The concentration of $\mathrm{CO}_{2}$ and $\mathrm{CH}_{4}$ in the headspace was measured with a gas chromatograph (model 5890; Hewlett Packard) fitted with Poropack R column (80/100 mesh, 1/8"o.d., 2m). Methane was quantified with a flame ionization detector. Carbon dioxide was converted to methane using a heated $\left(320^{\circ} \mathrm{C}\right)$ nickel catalyst and a hydrogen gas stream, and the resulting methane was measured with a flame ionization detector. Injector, column, and detector temperatures were, 150, 50 
and $300^{\circ} \mathrm{C}$, respectively. Peak areas for both gases were determined by electronic integration. Conversion of peak areas to moles of each gas was made by comparison to standards containing a known concentration of the gas. (Amador and Jones, 1995).

\subsection{Enzyme Activity Analysis}

The remaining soil left in each of the columns, after coring, was homogenized and half was used to analyze enzyme activity and the other half was used to analyze microbial biomass. Enzyme activities were determined on the soil from each of the columns via an assay using the fluorescent model substrate 4-methylumbelliferone (MUF) (Hoppe 1993; Sinsabaugh et al. 1997). Four enzyme substrates were used. They are 4-methylumbelliferyl-phosphate, MUF- $\beta-1-4-$

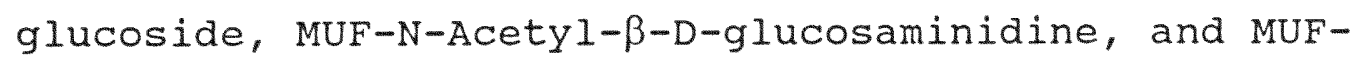
Sulfate. Approximately $1 \mathrm{~g}$ of soil slurry from each treatment column was diluted in distilled deionized water to achieve a soil solution ratio of about $1 \times 10^{-3}$. Samples were arranged in columns on a 96-multiwell plate ( 8 rows and 12 columns). From each treatment column eight replicate samples $(200 \mu \mathrm{l})$ were added to each of eight wells (one column) for each enzyme substrate to be analyzed. Next $50 \mu 1$ of $10 \mu \mathrm{M}$ MUF-X substrate $(\mathrm{X}=$ MUF-P, $-\mathrm{C},-\mathrm{N},-\mathrm{S})$ in $5 \mathrm{mM} \mathrm{pH}$ buffer was added to the samples in the upper four rows. This 
is the beginning of the incubation time. The upper four rows represent $t_{f}$ and the lower four represent $t_{0}$. Enzyme activity (EA) is determined from the difference between the amount of fluorescent substrate liberated during incubation time $\left(t_{f}\right)$ from time zero $\left(t_{0}\right)$. Previous experiments have shown maximum enzyme efficiencies of around $\mathrm{pH}=6$ for the glucosidase, glucosaminidase, and sulfatase enzymes, and a $\mathrm{pH}=8-9$ for alkaline phosphatase (Scinto et al., 1999). Fluorescence was measured in microplates on a fluorescent plate reader (Cytoflour 4000). Fluorescent wavelengths are $360 / 40 \mathrm{~nm}$ (wavelength/bandwidth) for excitation and $460 / 40 \mathrm{~nm}$ Incubations are conducted in the plates in the dark at $25^{\circ} \mathrm{C}$. After incubation and immediately before analysis $50 \mu \mathrm{l}$ of MUF-X substrate is added to the lower four rows of soil containing cells in each substrate series to provide $t_{0}$ readings. Prior to analysis all cells receive $10 \mu 1$ of $0.1 \mathrm{M}$ $\mathrm{NaOH}$ to bring the $\mathrm{pH}>10$; the $\mathrm{pH}$ at which the fluorophore has maximum fluorescence. Incubation times vary for the enzymes with phosphatase being read after $2 \mathrm{~h}$. The other enzyme activities are read after $24 \mathrm{~h}$ incubation. Results were reported as $\mu$ moles MUF-X substrate liberated $\mathrm{g}^{-1} \mathrm{dry}$ weight soil $\mathrm{h}^{-1}$ which is determined by comparison to standard curves generated from known concentrations of 4methylumbelliferone. 


\subsection{Bacterial Density}

Bacterial densities in the soil from each of the treated columns was determined by a flourometric assay using the double-stranded DNA stain Pico-Green (PG) (Molecular Probes). This method has been used to determine the bacterial densities in lake water and seawater (Tranvik 1997). The method has been adapted to determine bacterial densities on diluted soil and floc solutions (Scinto, P.C.). The method combines $1 \mathrm{ml}$ of sample (approx. $1 \mathrm{~g}$ of soil slurry is diluted in distilled deionized water to achieve a soil solution ratio of $1 \times 10^{3}$ ) with $10 \mu$ of $1 \%$ Triton $\mathrm{X}$, vortex mixing, and then allowing the solution to sit for ten minutes. After the initial incubation $125 \mu \mathrm{l}$ of this solution is pipetted into each of four wells (four analytical replicates of each sample) of a 96-well micro plate. The PG reagent is then added in equal volume (125 1 ) and the plates are shaken and allowed to incubate for an additional five minutes before fluorometric analysis. Analysis is conducted on a Cytofluor 4000 multiwell plate reader (Perseptive Biosystems, Inc.) at excitation wavelength $(E X C)=485 / 20$ and emission wavelength $($ EMM $)=$ $530 / 25$ (wave length/bandwidth) at a gain of 99 (maximum sensitivity) and with 10 reads/well. Blanks are made by identical protocol with exception that the samples are filtered $(0.2 \mu \mathrm{m})$ to remove intact bacteria before the 
addition of Triton $X$ at the initial stages of the protocol. Samples are compared to standards made from calf-thymus DNA in $\mathrm{TE}$ buffer in the range of $0-25 \mathrm{ng} \mathrm{ml}^{-1}$ (Molecular Probes Product support sheet).

\subsection{Nutrient Analysis}

Total $\mathrm{P}$ in soil and water samples were prepared according to the methods of Solorzano and Sharp, 1980. Total $\mathrm{p}$ was determined by oxidizing and hydrolyzing all of the phosphorus-containing compounds in a sample to soluble reactive phosphate, and determining the soluble reactive phosphorus concentration using an Alpkem autoanlyzer and the method described above. Carbon and nitrogen content of the soil was measured with a N/C analyzer (model NA 1500; Carlo Erba Instruments, s.p.a., Milan, Italy). Soil dry weight was determined by drying the soil to constant weight at $80^{\circ}$ C. Organic matter will be determined by loss on ignition at $550 \circ \mathrm{C}$ for two four hour periods (Nelson and Sommers, 1982) .

\section{O STATISTICS}

A one-way or two-way analysis of variance (ANOVA) in a randomized complete block was used to identify treatment effects on redox, microbial biomass, $\mathrm{CO}_{2}, \mathrm{CH}_{4}$, and $\mathrm{CO}_{2}$ and $\mathrm{CH}_{4}$ with depth in each treatment core. Tha analysis was adjusted for the differing initial soil phosphorus values by 
including it into the model as a main effect. For redox values the ANOVA was performed only on values obtained for each column on the last day of each experiment. Where significant results were obtained, Fisher's Least Significance Difference (LSD) test was used to differentiate between the means.

The student's $t$ test was used to test for significant differences in enzyme activity between treatment cores. The student's $t$ test was used due to missing data and therefore an F-test could not be done as the marginal means were not estimable with the missing data. All statistical analysis were performed using SPSS 7.5 for Windows and statistical significance was performed at $P \leq 0.05$.

\subsection{RESULTS AND DISCUSSION}

\subsection{Redox Potential}

A study was conducted to evaluate the differences in several microbial parameters in Everglades peat soils dosed with low, medium, and high phosphorus concentrations (0.5 $\mu \mathrm{M}, 1.0 \mu \mathrm{M}$, and $5.0 \mu \mathrm{M})$ and amended with glucose as a carbon source. The specific parameters measured were as follows: redox potential, $\mathrm{CO}_{2}$ and $\mathrm{CH}_{4}$ evolution, enzyme activity, and bacterial density. The initial redox potential for the control and three treatment columns stabilized around 500 $m V$. There was no decrease in redox potential observed in any of the soil columns when only $\mathrm{PO}_{4}$ was added. When glucose 
was added in addition to the phosphorus a significant decrease $(P=0.0007)$ in redox potential was observed between the control and the treatments as well as among the treatments. (Figure 5, Table 4). The redox potential was significantly lower in the soil columns treated with $0.5 \mu \mathrm{M}$ and $5.0 \mu \mathrm{MP} \quad(\mathrm{p}=0.003$ and $\mathrm{p}<0.001$ respectively, Fishers LSD) as compared to the control column. Additionally the redox potential was significantly lower in the high $\mathrm{P}$ column as compared to the low $\mathrm{PO}_{4}$ column $(\mathrm{p}=0.010)$. No effect of added $\mathrm{PO}_{4}$ was observed in the column increased with $1.0 \mu \mathrm{M}$ $\mathrm{PO}_{4}$ as compared to the control column $(\mathrm{p}=0.207)$. Patterns of redox potential resulting from added $\mathrm{PO}_{4}$ were also different among the treatment columns. The onset of reduction was observed to occur 1-2 days earlier in the high $\mathrm{PO}_{4}$ column as compared to the low $\mathrm{PO}_{4}$ column. The onset of reduction occurred within 3-5 days after glucose addition in the high $\mathrm{PO}_{4}$ column. Additionally the redox potential dropped much lower and more rapidly in the high $\mathrm{PO}_{4}$ column as compared to the low $\mathrm{PO}_{4}$ column. In general the experiment supports the hypothesis that increased phosphorus level results in shifts in the microbial communities from aerobically-dominated to anaerobically-dominated processes as shown by decreasing redox potential. In contrast, the $1.0 \mu \mathrm{M} \mathrm{PO}_{4}$ column did not become reduced. The reasons for this are unexplained. 

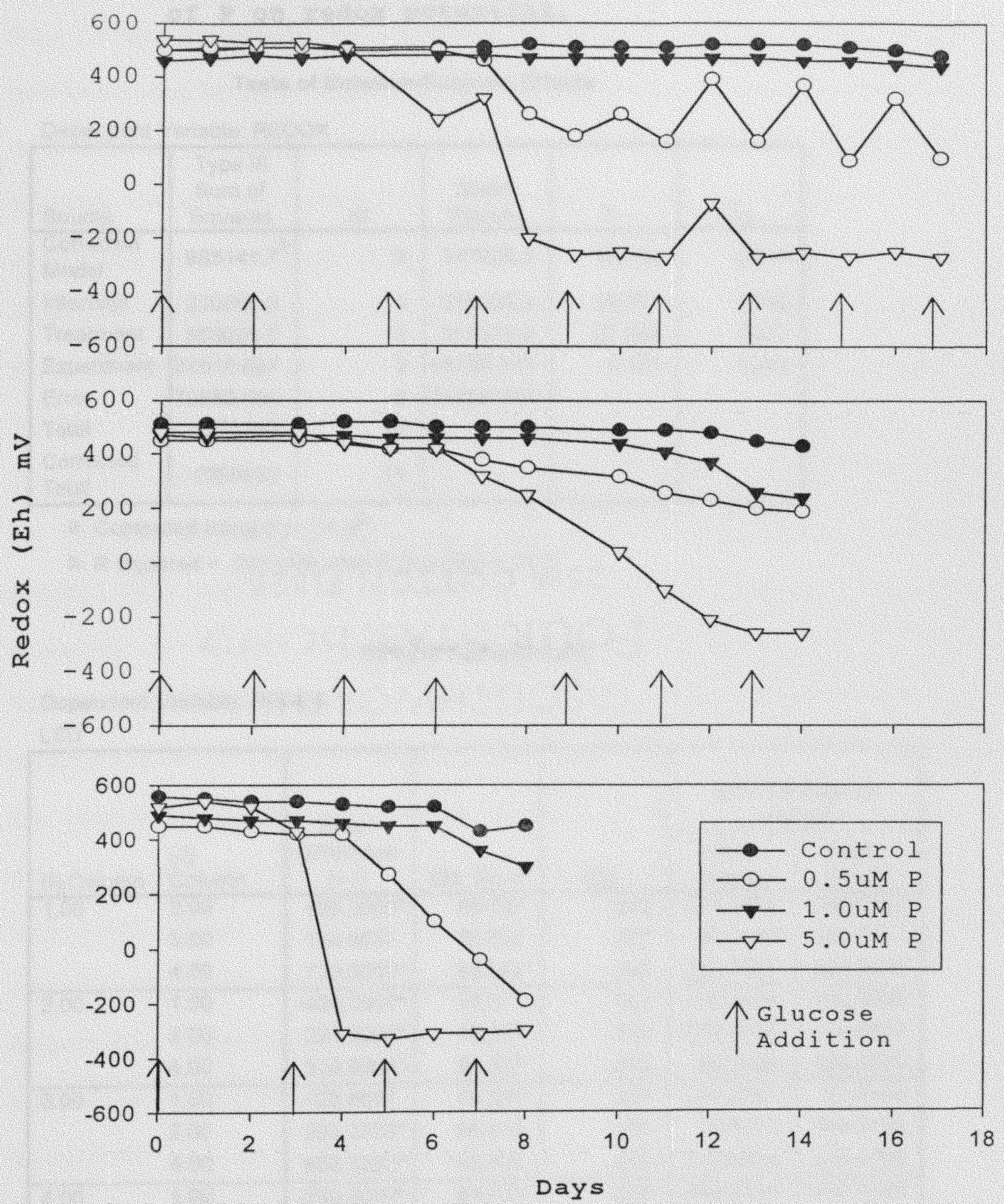

Figure 5: Effects of $P$ on redox potential for experiments 1,2 , and 3 (top to bottom). 
Table 4: ANOVA and Fisher's LSD table for the effects of $P$ on redox potential.

Tests of Between-Subjects Effects

Dependent Variable: REDOX

\begin{tabular}{|l|r|r|r|r|r|}
\hline Source & $\begin{array}{c}\text { Type III } \\
\text { Sum of } \\
\text { Squares }\end{array}$ & df & $\begin{array}{c}\text { Mean } \\
\text { Square }\end{array}$ & \multicolumn{1}{c|}{$F$} & Sig. \\
\hline Corrected & $985141.7^{b}$ & 5 & 197028.3 & 16.756 & .0018 \\
Model & 216008.3 & 1 & 216008.3 & 18.371 & .0052 \\
Intercept & 3 & 317875.0 & 27.034 & .0007 \\
Treatment & 953625.0 & 2 & 15758.333 & 1.340 & .3302 \\
Experiment & 31516.667 & 6 & 11758.333 & & \\
Error & 70550.000 & 12 & & & \\
Total & 1271700 & 11 & & & \\
Corrected & 1055692 & & & & \\
Total & & & & \\
\hline
\end{tabular}

a. Computed using alpha $=.05$

b. R Squared $=.933$ (Adjusted R Squared $=.877$ )

\section{Multiple Comparisons}

Dependent Variable: REDOX

LSD

\begin{tabular}{|c|c|c|c|c|c|c|}
\hline \multirow[b]{2}{*}{ (I) Column } & \multirow[b]{2}{*}{$\begin{array}{l}\text { (J) } \\
\text { Column }\end{array}$} & \multirow{2}{*}{$\begin{array}{c}\text { Mean } \\
\text { Difference } \\
(1-J)\end{array}$} & \multirow[b]{2}{*}{ Std. Error } & \multirow[b]{2}{*}{ Sig. } & \multicolumn{2}{|c|}{$\begin{array}{c}95 \% \text { Confidence } \\
\text { Interval }\end{array}$} \\
\hline & & & & & $\begin{array}{l}\text { Lower } \\
\text { Bound }\end{array}$ & $\begin{array}{l}\text { Upper } \\
\text { Bound }\end{array}$ \\
\hline \multirow[t]{3}{*}{1.00} & 2.00 & $420.0000^{*}$ & 88.537 & .003 & 203.3565 & 636.6435 \\
\hline & 3.00 & 126.6667 & 88.537 & .202 & -89.9768 & 343.3101 \\
\hline & 4.00 & $730.0000^{*}$ & 88.537 & .000 & 513.3565 & 946.6435 \\
\hline \multirow[t]{3}{*}{2.00} & 1.00 & $-420.0000^{*}$ & 88.537 & .003 & -636.6435 & -203.3565 \\
\hline & 3.00 & $-293.3333^{\star}$ & 88.537 & .016 & -509.9768 & -76.6899 \\
\hline & 4.00 & $310.0000^{\star}$ & 88.537 & .013 & 93.3565 & 526.6435 \\
\hline \multirow[t]{3}{*}{3.00} & 1.00 & -126.6667 & 88.537 & .202 & -343.3101 & 89.9768 \\
\hline & 2.00 & $293.3333^{*}$ & 88.537 & .016 & 76.6899 & 509.9768 \\
\hline & 4.00 & $603.3333^{*}$ & 88.537 & .000 & 386.6899 & 819.9768 \\
\hline \multirow[t]{3}{*}{4.00} & 1.00 & $-730.0000^{*}$ & 88.537 & .000 & -946.6435 & -513.3565 \\
\hline & 2.00 & $-310.0000^{*}$ & 88.537 & .013 & -526.6435 & -93.3565 \\
\hline & 3.00 & $-603.3333^{*}$ & 88.537 & .000 & -819.9768 & -386.6899 \\
\hline
\end{tabular}

Based on observed means. The error term is Error.

*. The mean difference is significant at the .05 level. 
The decreased redox potential observed due to added $\mathrm{PO}_{4}$ is an interesting finding as the pristine Everglades wetland soils are not highly reduced (anaerobic) (Bachoon and Jones, 1992). The Everglades wetlands have developed around relative nutrient starvation, and phosphorus is the limiting nutrient (Swift, 1981). Results from the South Florida Ecosystem Assessment Project (EPA, 1998), marsh soil Eh was measured in the Loxahatchee National Wildlife Refuge (LNWR), WCA-2, WCA-3, ENP, and in Big Cypress National Preserve (BCNP). In this Ecosystem Assessment the presence of an Eh less than $100 \mathrm{mV}$ is indicative of anoxic or reducing conditions occurring in the soils in the subarea. The only subarea in which the median Eh was found to be less than $100 \mathrm{mV}$ was WCA-2. It was also apparent, that while the occurrence of anoxia was exhibited in each of the subareas in isolated locations, most of the areas had oxic soil conditions. There are however, areas of the Everglades wetlands which have become eutrophic due to excess nutrient enrichment from agricultural drainage (Davis, 1994). Anaerobic conditions which may result from nutrient enrichment could lead to increased anaerobic microbial activity and the methylation of mercury.

The results of a study conducted by Drake et al., (1996) on the effects of nutrients on population profiles and activities in Everglades soils were comparable to those found here. The study found that Everglades sediments near 
sources of agricultural runoff had low redox potentials, were blackened with sulfide, and displayed high pore water TP concentrations and high water column conductivities. Additionally their findings demonstrated that Everglades sediments nearest agricultural runoff have enhanced anaerobic microbial profiles and that the anaerobic microflora are poised to respond rapidly to phosphate, sulfate, and nitrate input.

\section{$8.2 \mathrm{CO}_{2}$ and $\mathrm{CH}_{4}$ Production}

once the redox potentials of the soil columns were determined the columns were cored and segmented at $2 \mathrm{~cm}$ increments to compare $\mathrm{CO}_{2}$ and $\mathrm{CH}_{4}$ evolution from top to bottom within each core and with increasing concentration of $\mathrm{P}$ between the cores. The effects of $\mathrm{PO}_{4}$ additions on $\mathrm{CO}_{2}$ evolution are shown in Figure $6 . \mathrm{CO}_{2}$ evolution was marginally different between treatments $(p=0.0527)$ and was not significantly different with depth within a treatment column ( $\mathrm{p}=0.1429$ ) (Table 5). $\mathrm{CO}_{2}$ evolution in column one was significantly lower than the other three treatment columns; however there was no difference found between the treatment columns. It is interesting to note that in the third experiment, which produced the highest $\mathrm{CO}_{2}$ production, $\mathrm{CO}_{2}$ evolution was approximately 2.5 times higher in the treatment columns as compared to the control. These results suggest that evolution of $\mathrm{CO}_{2}$ from glucose was enhanced when 


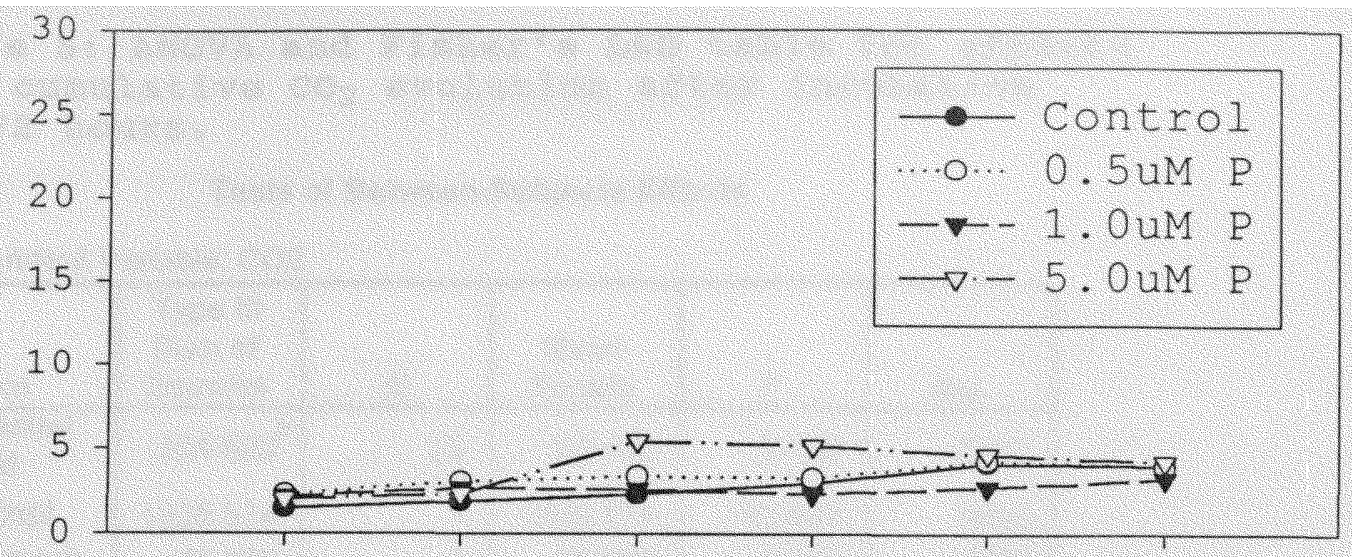

1
0
0
0
-1
0
5
3
5
5
0
5
4
0
4
4
5
0
0
5
0
0
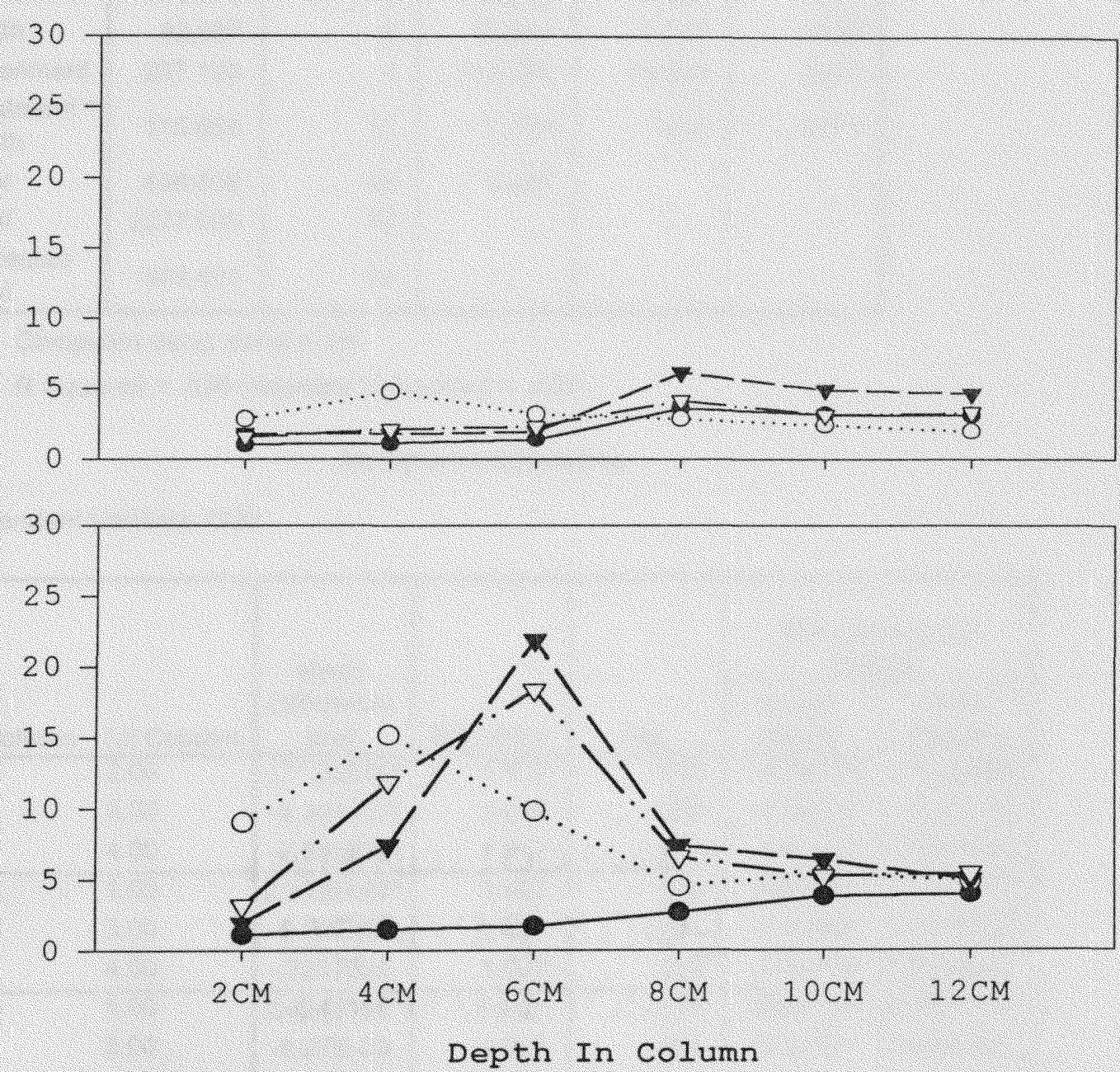

Eigure 6: Effects of $\mathrm{PO}_{4}$ additions on cumulative $\mathrm{CO}_{2}$ evolution after incubation for 72 hours for experiments 1,2 and 3 (top to bottom) 
Table 5: ANOVA and Fisher's LSD table for effects $\mathrm{p}$ on cumulative $\mathrm{CO}_{2}$ evolution after incubation for 72 hours.

Tests of Between-Subjects Effects

Dependent Variable: $\mathrm{CO} 2$

\begin{tabular}{|l|r|r|r|r|r|}
\hline Source & \multicolumn{1}{|c|}{$\begin{array}{c}\text { Type III } \\
\text { Sum of } \\
\text { Squares }\end{array}$} & df & \multicolumn{1}{c|}{$\begin{array}{c}\text { Mean } \\
\text { Square }\end{array}$} & \multicolumn{1}{c|}{$F$} & Sig. \\
\hline Corrected & $504.623^{\mathrm{b}}$ & 25 & 20.185 & 2.126 & .0132 \\
Model & 1335.574 & 1 & 1335.574 & 140.649 & .0000 \\
Intercept & 78.670 & 3 & 26.223 & 2.762 & .0527 \\
Treatment & 82.957 & 5 & 16.591 & 1.747 & .1429 \\
Depth & 227.129 & 2 & 113.564 & 11.959 & .0001 \\
Experiment & 115.868 & 15 & 7.725 & .813 & .6577 \\
Treatment * & 436.808 & 46 & 9.496 & & \\
Depth & 2277.005 & 72 & & & \\
Error & 941.431 & 71 & & & \\
Total & & & & \\
Corrected & Total & & & & \\
\hline
\end{tabular}

a. Computed using alpha $=.05$

b. $R$ Squared $=.536$ (Adjusted $R$ Squared $=.284$ )

Multiple Comparisons

Dependent Variable: $\mathrm{CO} 2$

LSD

\begin{tabular}{|c|c|c|c|c|c|c|}
\hline \multirow[b]{2}{*}{ (1) Column } & \multirow[b]{2}{*}{ (J) Column } & \multirow{2}{*}{$\begin{array}{c}\text { Mean } \\
\text { Difference } \\
(1-J)\end{array}$} & \multirow[b]{2}{*}{ Std. Error } & \multirow[b]{2}{*}{ Sig. } & \multicolumn{2}{|c|}{$\begin{array}{c}95 \% \text { Confidence } \\
\text { Interval }\end{array}$} \\
\hline & & & & & $\begin{array}{l}\text { Lower } \\
\text { Bound }\end{array}$ & $\begin{array}{l}\text { Upper } \\
\text { Bound }\end{array}$ \\
\hline \multirow[t]{3}{*}{1.00} & 2.00 & $-2.332589^{*}$ & 1.027 & .028 & -4.40019 & -.2649903 \\
\hline & 3.00 & $-2.324317^{\star}$ & 1.027 & .028 & -4.39192 & -.2567185 \\
\hline & 4.00 & $-2.556321^{*}$ & 1.027 & .017 & -4.62392 & -.4887231 \\
\hline \multirow[t]{3}{*}{2.00} & 1.00 & $2.3325887^{*}$ & 1.027 & .028 & .2649903 & 4.4001872 \\
\hline & 3.00 & 8.27E-03 & 1.027 & .994 & -2.05933 & 2.0758702 \\
\hline & 4.00 & -.2237328 & 1.027 & .829 & -2.29133 & 1.8438657 \\
\hline \multirow[t]{3}{*}{3.00} & 1.00 & $2.3243169^{\star}$ & 1.027 & .028 & .2567185 & 4.3919154 \\
\hline & 2.00 & $-8.27 E-03$ & 1.027 & .994 & -2.07587 & 2.0593267 \\
\hline & 4.00 & -.2320046 & 1.027 & .822 & -2.29960 & 1.8355939 \\
\hline \multirow[t]{3}{*}{4.00} & 1.00 & $2.5563215^{\star}$ & 1.027 & .017 & 4887231 & 4.6239199 \\
\hline & 2.00 & .2237328 & 1.027 & .829 & -1.84387 & 2.2913312 \\
\hline & 3.00 & .2320046 & 1.027 & .822 & -1.83559 & 2.2996030 \\
\hline
\end{tabular}

Based on observed means. The error term is Error.

${ }^{*}$. The mean difference is significant at the .05 level. 
Table 5 continued

Multiple Comparisons

Dependent Variable: $\mathrm{CO} 2$

\begin{tabular}{|c|c|c|c|c|c|c|}
\hline \multirow[b]{2}{*}{ (1) DEPTH } & \multirow[b]{2}{*}{ (J) DEPTH } & \multirow{2}{*}{$\begin{array}{c}\text { Mean } \\
\text { Difference } \\
(1-J) \\
\end{array}$} & \multirow[b]{2}{*}{ Std. Error } & \multirow[b]{2}{*}{ Sig. } & \multicolumn{2}{|c|}{$\begin{array}{c}95 \% \text { Confidence } \\
\text { Interval } \\
\end{array}$} \\
\hline & & & & & $\begin{array}{l}\text { Lower } \\
\text { Bound }\end{array}$ & $\begin{array}{l}\text { Upper } \\
\text { Bound }\end{array}$ \\
\hline \multirow[t]{5}{*}{2.00} & 4.00 & -2.094471 & 1.258 & .103 & -4.62675 & 4378091 \\
\hline & 6.00 & $-3.654979^{*}$ & 1.258 & .006 & -6.18726 & -1.12270 \\
\hline & 8.00 & -1.764206 & 1.258 & .168 & -4.29649 & .7680744 \\
\hline & 10.00 & -1.654804 & 1.258 & .195 & -4.18708 & .8774769 \\
\hline & 12.00 & -1.440676 & 1.258 & .258 & -3.97296 & 1.0916047 \\
\hline \multirow[t]{5}{*}{4.00} & 2.00 & 2.0944715 & 1.258 & .103 & -.4378091 & 4.6267521 \\
\hline & 6.00 & -1.560507 & 1.258 & .221 & -4.09279 & .9717735 \\
\hline & 8.00 & .3302653 & 1.258 & .794 & -2.20202 & 2.8625459 \\
\hline & 10.00 & .4396678 & 1.258 & .728 & -2.09261 & 2.9719484 \\
\hline & 12.00 & .6537957 & 1.258 & .606 & -1.87848 & 3.1860762 \\
\hline \multirow[t]{5}{*}{6.00} & 2.00 & $3.6549786^{*}$ & 1.258 & .006 & 1.1226980 & 6.1872592 \\
\hline & 4.00 & 1.5605071 & 1.258 & .221 & -.9717735 & 4.0927877 \\
\hline & 8.00 & 1.8907724 & 1.258 & .140 & -.6415082 & 4.4230530 \\
\hline & 10.00 & 2.0001749 & 1.258 & .119 & -.5321057 & 4.5324555 \\
\hline & 12.00 & 2.2143027 & 1.258 & .085 & -.3179778 & 4.7465833 \\
\hline \multirow[t]{5}{*}{8.00} & 2.00 & 1.7642062 & 1.258 & .168 & -.7680744 & 4.2964867 \\
\hline & 4.00 & -.3302653 & 1.258 & .794 & -2.86255 & 2.2020152 \\
\hline & 6.00 & -1.890772 & 1.258 & .140 & -4.42305 & .6415082 \\
\hline & 10.00 & .1094025 & 1.258 & .931 & -2.42288 & 2.6416831 \\
\hline & 12.00 & .3235303 & 1.258 & .798 & -2.20875 & 2.8558109 \\
\hline \multirow[t]{5}{*}{10.00} & 2.00 & 1.6548037 & 1.258 & .195 & -.8774769 & 4.1870842 \\
\hline & 4.00 & -.4396678 & 1.258 & .728 & -2.97195 & 2.0926127 \\
\hline & 6.00 & -2.000175 & 1.258 & .119 & -4.53246 & .5321057 \\
\hline & 8.00 & -.1094025 & 1.258 & .931 & -2.64168 & 2.4228781 \\
\hline & 12.00 & .2141278 & 1.258 & .866 & -2.31815 & 2.7464084 \\
\hline \multirow[t]{5}{*}{12.00} & 2.00 & 1.4406758 & 1.258 & .258 & -1.09160 & 3.9729564 \\
\hline & 4.00 & -.6537957 & 1.258 & .606 & -3.18608 & 1.8784849 \\
\hline & 6.00 & -2.214303 & 1.258 & .085 & -4.74658 & .3179778 \\
\hline & 8.00 & -3235303 & 1.258 & .798 & -2.85581 & 2.2087502 \\
\hline & 10.00 & -.2141278 & 1.258 & .866 & -2.74641 & 2.3181527 \\
\hline
\end{tabular}

Based on observed means. The error term is Error.

*. The mean difference is significant at the .05 level. 
$P$ was added to the soil, suggesting limitation of $C$ mineralization by $\mathrm{P}$ availability. The values obtained for $\mathrm{CO}_{2}$ evolution compare with published results for peat soils of the Florida Everglades. In this system total $\mathrm{CO}_{2}$ evolution per column ranged across treatments from 4 to 19 mmolc kg-1 $\mathrm{d}^{-1}$. In a study conducted by Amador and Jones (1993) $\mathrm{CO}_{2}$ evolution for low TP soil (0.231 $\mathrm{g}_{\text {total }} \mathrm{P} \mathrm{kg}^{-1}$ ) amended with $\mathrm{PO}_{4}$ ranged from $32 \pm 1$ to $47 \pm 1$ molc $\mathrm{kg}^{-1} \mathrm{~d}^{-}$ 1. In a more recent study conducted by Amador and Jones (1995) $\mathrm{CO}_{2}$ concentrations in low TP soil amended with glucose were reported to range from $16 \pm 6$ to $49 \pm 5$ molc $\mathrm{kg}^{-1} \mathrm{~d}^{-1}$. Carbon dioxide evolution in the above studies is higher than observed in this study, however their incubation period was for twenty-nine days versus three days in this study. The Amador and Jones (1995) study also found that addition of $\mathrm{P}$ to the low $T P$ soil resulted in a significant increase in cumulative $\mathrm{CO}_{2}$ evolved per mole of added $\mathrm{C}$ when the soil was amended with acetate, glucose, or sawgrass. This is similar to the results observed with addition of $P$ when the soil was amended with glucose. In a study conducted by DeBusk and Reddy (1997) flux of $\mathrm{CO}_{2}$ in peat and overlying litter layer was found to increase significantly with increasing TP concentration. This was observed along a nutrient gradient in $\mathrm{WCA}-2$. These studies along with results from this study all demonstrate that the rate of organic $C$ 
turnover in peat soils of the Everglades is significantly enhanced by increased $\mathrm{PO}_{4}$ loading.

The effects of $\mathrm{PO}_{4}$ additions on $\mathrm{CH}_{4}$ evolution are shown in Figure $7 . \mathrm{CH}_{4}$ evolution was significantly different between treatments $(p=0.0158)$ and with depth within a treatment column $(\mathrm{p}=0.0002)$ (Table 6$) \cdot \mathrm{CH}_{4}$ evolution in column two was significantly higher than column one $(\mathrm{p}=$ $0.002)$ and column three $(p=0.050)$. There was no significant difference found between treatment columns one and four or between columns one and three. Methane evolution was also measured at $2 \mathrm{~cm}$ depth increments within each treatment column. A trend was found that $\mathrm{CH}_{4}$ evolution increased with increasing depth.

In this system total $\mathrm{CH}_{4}$ evolution ranged across treatments from $0.0-0.0731 \mu$ moles $\mathrm{CH}_{4} \mathrm{~g}^{-1}$ wet weight $\mathrm{d}^{-1}$. Amador and Jones (1995) reported methane production, calculated from four to nine days, in their low treatment to range from 20-48 mmol $\mathrm{CH}_{4} \mathrm{~kg}^{-1} \mathrm{~d}^{-1}$. These values are much higher than those found in this study due to several reasons. In the study conducted by Amador and Jones (1995) lag times before $\mathrm{CH}_{4}$ evolution occurred in the low TP soil was from 7 to 14 days. The soil in this study was incubated for 72 hours. Another explanation for the low methanogenesis response is the rate at which glucose is converted to methanogenic substrates. Under natural conditions, methanogens in freshwater sediments can utilize only a small 


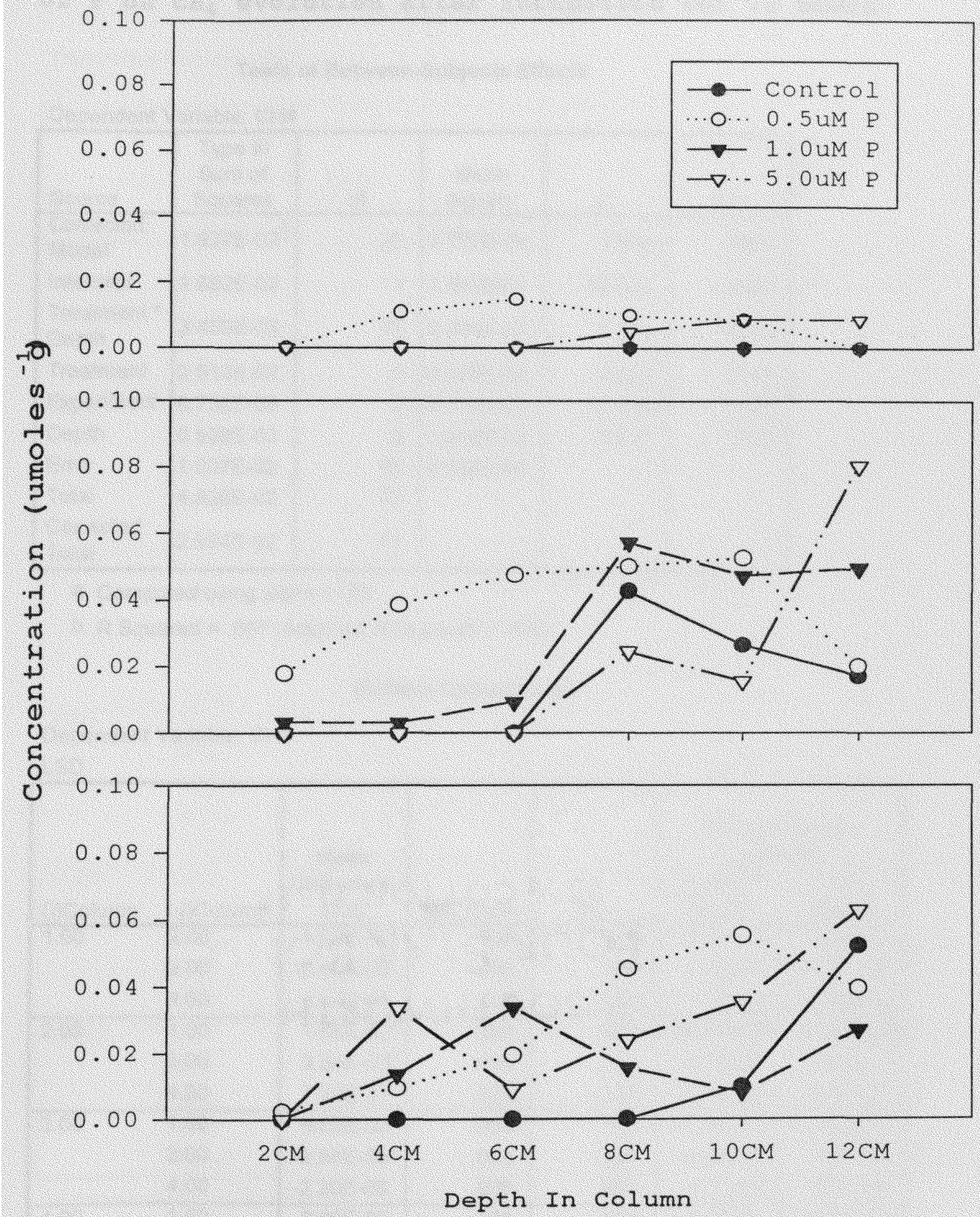

Eigure 7: Effects of $\mathrm{P}$ on cumulative $\mathrm{CH}_{4}$ evolution after incubation for 72 hours for experiments 1,2 , and 3 (top to bottom). 
Table 6: ANOVA and Fisher's LSD table for effects of $\mathrm{P}$ on $\mathrm{CH}_{4}$ evolution after incubation for 72 hours.

Tests of Between-Subjects Effects

Dependent Variable: $\mathrm{CH} 4$

\begin{tabular}{|c|c|c|c|c|c|}
\hline Source & $\begin{array}{l}\text { Type III } \\
\text { Sum of } \\
\text { Squares }\end{array}$ & df & $\begin{array}{l}\text { Mean } \\
\text { Square }\end{array}$ & $F$ & Sig. \\
\hline $\begin{array}{l}\text { Corrected } \\
\text { Model }\end{array}$ & $1.927 E-02^{b}$ & 25 & 7.707E-04 & 3.519 & .0001 \\
\hline Intercept & $1.892 E-02$ & 1 & $1.892 E-02$ & 86.409 & .0000 \\
\hline $\begin{array}{l}\text { Treatment * } \\
\text { Depth }\end{array}$ & $3.459 \mathrm{E}-03$ & 15 & $2.306 E-04$ & 1.053 & .4231 \\
\hline Treatment & 2.513E-03 & 3 & 8.375E-04 & 3.824 & .0158 \\
\hline Experiment & $6.758 E-03$ & 2 & $3.379 E-03$ & 15.430 & .0000 \\
\hline Depth & $6.538 E-03$ & 5 & $1.308 E-03$ & 5.971 & .0002 \\
\hline Error & $1.007 E-02$ & 46 & 2.190E-04 & & \\
\hline Total & 4.826E-02 & 72 & & & \\
\hline $\begin{array}{l}\text { Corrected } \\
\text { Total }\end{array}$ & $2.934 E-02$ & 71 & & & \\
\hline
\end{tabular}

a. Computed using alpha $=.05$

b. R Squared $=.657$ (Adjusted R Squared $=.470$ )

\section{Multiple Comparisons}

Dependent Variable: $\mathrm{CH} 4$

LSD

\begin{tabular}{|c|c|c|c|c|c|c|}
\hline \multirow[b]{2}{*}{ (I)Column } & \multirow[b]{2}{*}{ (J)Column } & \multirow{2}{*}{$\begin{array}{c}\text { Mean } \\
\text { Difference } \\
(1-J)\end{array}$} & \multirow[b]{2}{*}{ Std. Error } & \multirow[b]{2}{*}{ Sig. } & \multicolumn{2}{|c|}{$\begin{array}{c}95 \% \text { Confidence } \\
\text { Interval }\end{array}$} \\
\hline & & & & & $\begin{array}{l}\text { Lower } \\
\text { Bound } \\
\end{array}$ & $\begin{array}{l}\text { Upper } \\
\text { Bound } \\
\end{array}$ \\
\hline \multirow[t]{3}{*}{1.00} & 2.00 & $-1.65 \mathrm{E}-02^{*}$ & .005 & .002 & $-2.6 E-02$ & $-6.6 E-03$ \\
\hline & 3.00 & $-6.60 E-03$ & .005 & .188 & $-1.7 E-02$ & 3.33E-03 \\
\hline & 4.00 & $-8.80 E-03$ & .005 & .081 & $-1.9 E-02$ & 1.13E-03 \\
\hline \multirow[t]{3}{*}{2.00} & 1.00 & $1.65 \mathrm{E}-02^{*}$ & .005 & .002 & $6.61 E-03$ & $2.65 E-02$ \\
\hline & 3.00 & $9.94 \mathrm{E}-03^{*}$ & .005 & .050 & $1.56 E-05$ & $1.99 E-02$ \\
\hline & 4.00 & $7.74 E-03$ & .005 & .123 & $-2.2 E-03$ & $1.77 E-02$ \\
\hline \multirow[t]{3}{*}{3.00} & 1.00 & $6.60 E-03$ & .005 & .188 & $-3.3 E-03$ & $1.65 E-02$ \\
\hline & 2.00 & $-9.94 \mathrm{E}-03^{*}$ & .005 & .050 & $-2.0 E-02$ & $-1.6 E-05$ \\
\hline & 4.00 & $-2.20 E-03$ & .005 & .657 & $-1.2 E-02$ & $7.72 E-03$ \\
\hline \multirow[t]{3}{*}{4.00} & 1.00 & $8.80 E-03$ & .005 & .081 & $-1.1 E-03$ & $1.87 E-02$ \\
\hline & 2.00 & $-7.74 E-03$ & .005 & .123 & $-1.8 E-02$ & 2.19E-03 \\
\hline & 3.00 & $2.20 \mathrm{E}-03$ & .005 & .657 & $-7.7 E-03$ & $1.21 E-02$ \\
\hline
\end{tabular}

Based on observed means. The error term is Error.

*. The mean difference is significant at the .05 level. 
Table 6 continued

Multiple Comparisons

Dependent Variable: $\mathrm{CH}_{4}$

LSD

\begin{tabular}{|c|c|c|c|c|c|c|}
\hline \multirow[b]{2}{*}{ (I) DEPTH } & \multirow[b]{2}{*}{ (J) DEPTH } & \multirow{2}{*}{$\begin{array}{c}\text { Mean } \\
\text { Difference } \\
(1-J)\end{array}$} & \multirow[b]{2}{*}{ Std. Error } & \multirow[b]{2}{*}{ Sig. } & \multicolumn{2}{|c|}{$\begin{array}{c}95 \% \text { Confidence } \\
\text { Interval } \\
\end{array}$} \\
\hline & & & & & $\begin{array}{l}\text { Lower } \\
\text { Bound }\end{array}$ & $\begin{array}{l}\text { Upper } \\
\text { Bound }\end{array}$ \\
\hline \multirow[t]{5}{*}{2.00} & 4.00 & $-7.13 E-03$ & .006 & .244 & $-1.9 E-02$ & $5.03 E-03$ \\
\hline & 6.00 & $-9.16 E-03$ & .006 & .136 & $-2.1 E-02$ & $3.00 E-03$ \\
\hline & 8.00 & $-2.08 E-02^{*}$ & .006 & .001 & $-3.3 E-02$ & $-8.7 E-03$ \\
\hline & 10.00 & $-2.07 E-02^{*}$ & .006 & .001 & $-3.3 E-02$ & $-8.5 E-03$ \\
\hline & 12.00 & $-2.77 E-02 *$ & .006 & .000 & $-4.0 E-02$ & $-1.6 E-02$ \\
\hline \multirow[t]{5}{*}{4.00} & 2.00 & $7.13 E-03$ & .006 & .244 & $-5.0 E-03$ & $1.93 E-02$ \\
\hline & 6.00 & $-2.03 E-03$ & .006 & .738 & $-1.4 E-02$ & $1.01 E-02$ \\
\hline & 8.00 & $-1.37 E-02^{*}$ & .006 & .028 & $-2.6 E-02$ & $-1.5 E-03$ \\
\hline & 10.00 & $-1.35 E-02 *$ & .006 & .030 & $-2.6 E-02$ & $-1.4 E-03$ \\
\hline & 12.00 & $-2.06 E-02^{*}$ & .006 & .001 & $-3.3 E-02$ & $-8.4 E-03$ \\
\hline \multirow[t]{5}{*}{6.00} & 2.00 & $9.16 E-03$ & .006 & .136 & $-3.0 \mathrm{E}-03$ & 2.13E-02 \\
\hline & 4.00 & $2.03 E-03$ & .006 & .738 & $-1.0 E-02$ & $1.42 E-02$ \\
\hline & 8.00 & $-1.17 E-02$ & .006 & .060 & $-2.4 E-02$ & $4.88 E-04$ \\
\hline & 10.00 & $-1.15 E-02$ & .006 & .063 & $-2.4 E-02$ & $6.59 E-04$ \\
\hline & 12.00 & $-1.85 E-02^{*}$ & .006 & .004 & $-3.1 E-02$ & $-6.4 E-03$ \\
\hline \multirow[t]{5}{*}{8.00} & 2.00 & $2.08 E-02^{*}$ & .006 & .001 & $8.67 E-03$ & $3.30 E-02$ \\
\hline & 4.00 & $1.37 E-02^{*}$ & .006 & .028 & $1.54 E-03$ & $2.59 E-02$ \\
\hline & 6.00 & $1.17 E-02$ & .006 & .060 & $-4.9 E-04$ & 2.38E-02 \\
\hline & 10.00 & $1.71 E-04$ & .006 & .978 & $-1.2 E-02$ & 1.23E-02 \\
\hline & 12.00 & $-6.86 E-03$ & .006 & .262 & $-1.9 E-02$ & $5.30 E-03$ \\
\hline \multirow[t]{5}{*}{10.00} & 2.00 & $2.07 E-02^{*}$ & .006 & .001 & $8.50 E-03$ & $3.28 \mathrm{E}-02$ \\
\hline & 4.00 & $1.35 E-02^{*}$ & .006 & .030 & 1.37E-03 & 2.57E-02 \\
\hline & 6.00 & $1.15 E-02$ & .006 & .063 & $-6.6 E-04$ & 2.37E-02 \\
\hline & 8.00 & $-1.71 E-04$ & .006 & .978 & $-1.2 E-02$ & $1.20 E-02$ \\
\hline & 12.00 & $-7.03 E-03$ & .006 & .250 & $-1.9 E-02$ & $5.13 E-03$ \\
\hline \multirow[t]{5}{*}{12.00} & 2.00 & $2.77 E-02^{*}$ & .006 & .000 & $1.55 E_{-02}$ & $3.99 E-02$ \\
\hline & 4.00 & $2.06 E-02^{*}$ & .006 & .001 & $8.41 E-03$ & $3.27 E-02$ \\
\hline & 6.00 & $1,85 E-02^{*}$ & .006 & .004 & $6.38 \mathrm{E}-03$ & 3.07E-02 \\
\hline & 8.00 & $6.86 E-03$ & .006 & .262 & $-5.3 E-03$ & $1.90 E-02$ \\
\hline & 10.00 & $7.03 E-03$ & .006 & .250 & $-5.1 E-03$ & $1.92 E-02$ \\
\hline
\end{tabular}

Based on observed means. The error term is Error.

*. The mean difference is significant at the .05 level. 
portion of the organic substrate pool, mainly acetate (Crill et al. 1991). The fermentative metabolism of glucose may have shifted to products other than acetate, such that acetate production was not sufficient to meet the needs of the methanogenic bacteria in the soil from my reduced columns (Amador and Jones, 1995).

\subsection{Enzyme Activity and Microbial Biomass}

After the columns were cored to determine $\mathrm{CO}_{2}$ and $\mathrm{CH}_{4}$ evolution the remaining soil in each of the columns was used to determine enzyme activity and microbial biomass. In the first experiment conducted the soil for column four was lost and therefore could not be analyzed.

The results of the effects of $\mathrm{PO}_{4}$ on enzyme activity can be seen in Table 7 . There was no significant difference between treatments for any of the enzymes analyzed; however there are some interesting things to note from looking at the individual experiments.

Since inorganic phosphate is found in growth limiting concentrations in the Everglades, one of the most important microbial activities is the conversion of organic phosphates to inorganic phosphates through the action of phosphatases (Jones, 1993). Alkaline phosphatase (APA) activity can be seen in Figure 8. In comparing experiments, APA activity was close to four times higher in experiment one as compared to experiment three. 
Table 7: student's T-Test table for effects of $p$ on enzyme activity.

\begin{tabular}{|c|c|c|c|c|c|c|}
\hline & & \multicolumn{5}{|c|}{ t-test for Equality of Means } \\
\hline & & $\mathrm{t}$ & df & $\begin{array}{c}\text { Sig. } \\
\text { (2-tailed) }\end{array}$ & $\begin{array}{c}\text { Mean } \\
\text { Difference }\end{array}$ & $\begin{array}{l}\text { Std. Error } \\
\text { Difference }\end{array}$ \\
\hline $\bar{N}$ & $\begin{array}{l}\text { Equal } \\
\text { variances } \\
\text { assumed } \\
\text { Equal } \\
\text { variances } \\
\text { not } \\
\text { assumed }\end{array}$ & $\begin{array}{l}-.106 \\
-.106\end{array}$ & 3.994 & .921 & $\begin{array}{l}-2.00 E-03 \\
-2.00 E-03\end{array}$ & $\begin{array}{l}1.893 E-02 \\
1.893 E-02\end{array}$ \\
\hline$P$ & $\begin{array}{l}\text { Equal } \\
\text { variances } \\
\text { assumed } \\
\text { Equal } \\
\text { variances } \\
\text { not } \\
\text { assumed }\end{array}$ & .014 & 3.999 & .989 & $\begin{array}{l}7.333 E-03 \\
7.333 E-03\end{array}$ & .516147 \\
\hline$S$ & $\begin{array}{l}\text { Equal } \\
\text { variances } \\
\text { assumed } \\
\text { Equal } \\
\text { variances } \\
\text { not } \\
\text { assumed }\end{array}$ & .211 & 3.888 & .843 & 6.333E-04 & $\begin{array}{l}3.005 E-03 \\
3.005 E-03\end{array}$ \\
\hline $\mathrm{C}$ & $\begin{array}{l}\text { Equal } \\
\text { variances } \\
\text { assumed } \\
\text { Equal } \\
\text { variances } \\
\text { not } \\
\text { assumed }\end{array}$ & $\begin{array}{l}-.499 \\
-.499\end{array}$ & 3.636 & .647 & $-1.47 E-02$ & 2.940E-02 \\
\hline
\end{tabular}


In addition the treatment columns become reduced twice as fast in experiment three as compared to experiment one. The more rapid onset of anaerobic respiration and higher APA activity appears to have been a result of the differences in the original soil $\mathrm{P}$ levels detected in the first and third experiments (Table 3 ). The soil $\mathrm{P}$ concentration in the first experiment was almost half that of the soil $P$ concentration in the third experiment. The lower soil $\mathrm{P}$ concentration in the first experiment appears to have resulted in the increased APA activity and the slower onset of anaerobic respiration. In addition under anaerobic conditions phosphorus becomes more available due to the solubilization of ferric phosphate minerals (Moore and Reddy, 1994) resulting in a diminished need for APA to be produced. Also in experiment three APA activity in column four was much lower than the other treatment columns. This appears to be due to the level of phosphorus added to this column and the rapid rate at which this column became reduced. Based on these results it appears that APA activity decreases related to how quickly the soil responds to the added $\mathrm{PO}_{4}$ and the amount of $\mathrm{PO}_{4}$ that is added. In experiment two the APA assay was not conducted at its optimum $\mathrm{pH}$ value and the results had to be adjusted which may explain the low response for APA activity observed in this experiment. 


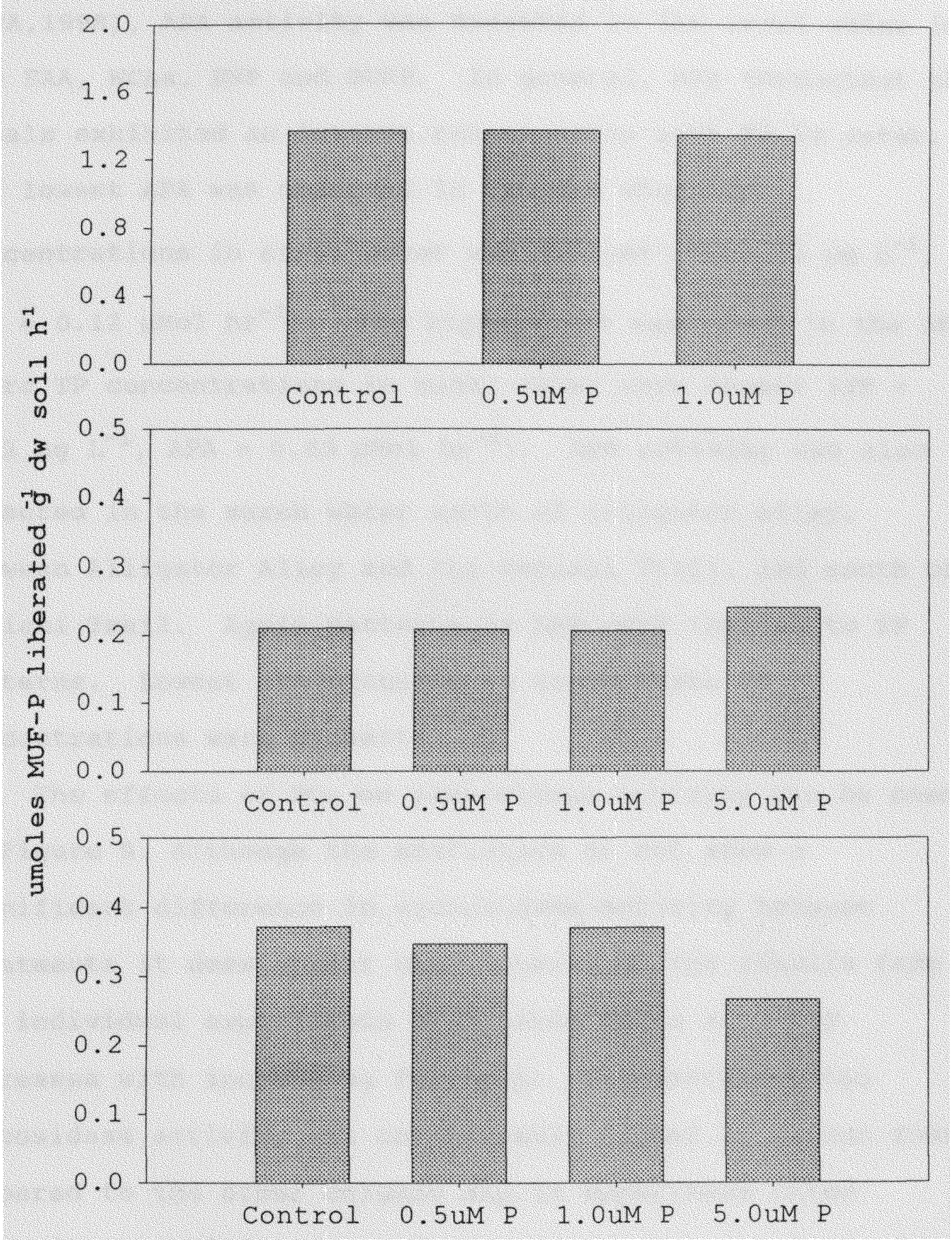

Figure 8: Effects of $\mathrm{P}$ on alkaline phosphatase activity in experiments 1, 2, and 3 (top to bottom). 
In the South Florida Ecosystem Assessment Report (EPA, 1998), APA activity was measured in the canal water in the EAA, WCAs, ENP and BCNP. In general, APA throughout the canals exhibited an inverse relationship with TP in water. The lowest APA was observed in the EAA where TP concentrations in canal water was highest $\left(\mathrm{TP}=73 \mu \mathrm{g} \mathrm{L} \mathrm{L}^{-1}\right.$,

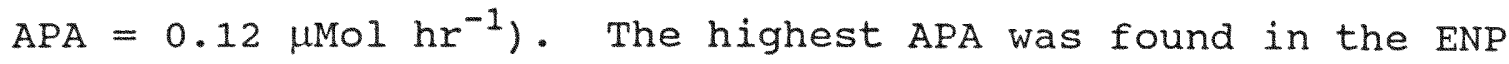
where TP concentrations in canal water were lowest $(\mathrm{TP}=$ $\left.14.2 \mu \mathrm{g} \mathrm{L} \mathrm{L}^{-1}, \mathrm{APA}=0.65 \mu \mathrm{Mol} \mathrm{hr}^{-1}\right)$. APA activity was also measured in the marsh water north of Alligator Alley, between Alligator Alley and the Tamiami Trail, and south of Tamiami Trail. Again patterns of APA were inverse to TP patterns. Lowest APA occurred in areas where TP concentrations were highest.

The effects of $\mathrm{PO}_{4}$ on glucosidase activity can be seen in Figure 9. Although the statistics do not show a significant difference in glucosidase activity between treatments it does appear when looking at the results from the individual experiments that glucosidase activity increases with increasing $\mathrm{PO}_{4}$ level. In experiment two glucosidase activity was considerably higher in column four compared to the other columns and in experiment three glucosidase activity was considerably higher in column four than columns one and two. It appears that glucosidase activity does increase with increasing $\mathrm{P}$ concentration and therefore it would also be expected that degradation of 


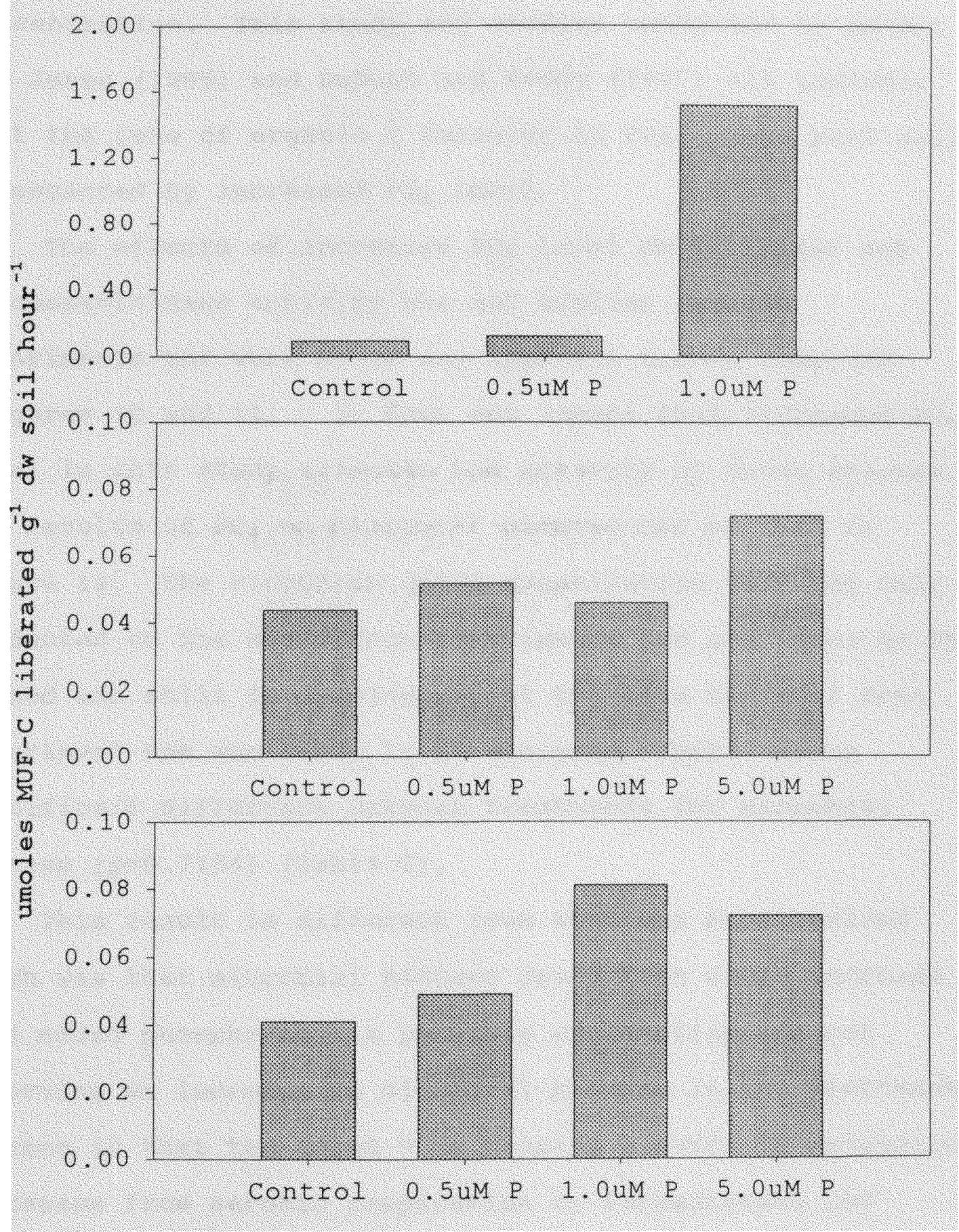

Figure 9: Effects of $P$ on glucosidase activity for experiments 1, 2, and 3 (top to bottom). 
organic matter would increase with increasing $P$ concentration. This study and studies conducted by Amador and Jones (1995) and DeBusk and Reddy (1997) all indicate that the rate of organic $C$ turnover in Everglades peat soil is enhanced by increased $\mathrm{PO}_{4}$ level.

The effects of increased $\mathrm{PO}_{4}$ level on sulfatase and glucoseaminidase activity was not similar between experiments nor were there any apparent trends observed (Figures 10 and 11). It does not appear that increased $\mathrm{PO}_{4}$ level in this study effected the activity of these enzymes. The results of $\mathrm{PO}_{4}$ on microbial biomass can be seen in Figure 12. The PicoGreen dsDNA quantitation test was only conducted on the soils from experiments two and three as the method was still in development at the time the soil from experiment one was ready to be analyzed. There was no significant difference between treatments for microbial biomass $(p=0.7154)$ (Table 8$)$.

This result is different from what was hypothesized which was that microbial biomass production would increase with added phosphorus. A possible explanation for not observing an increase in microbial biomass in the treatment columns is that the added $P$ is causing a shift in metabolic processes from aerobic respiration to fermentation and anaerobic respiration. Anaerobic respiration or fermentation release less energy to microorganisms than the complete aerobic degradation of organic matter to carbon 


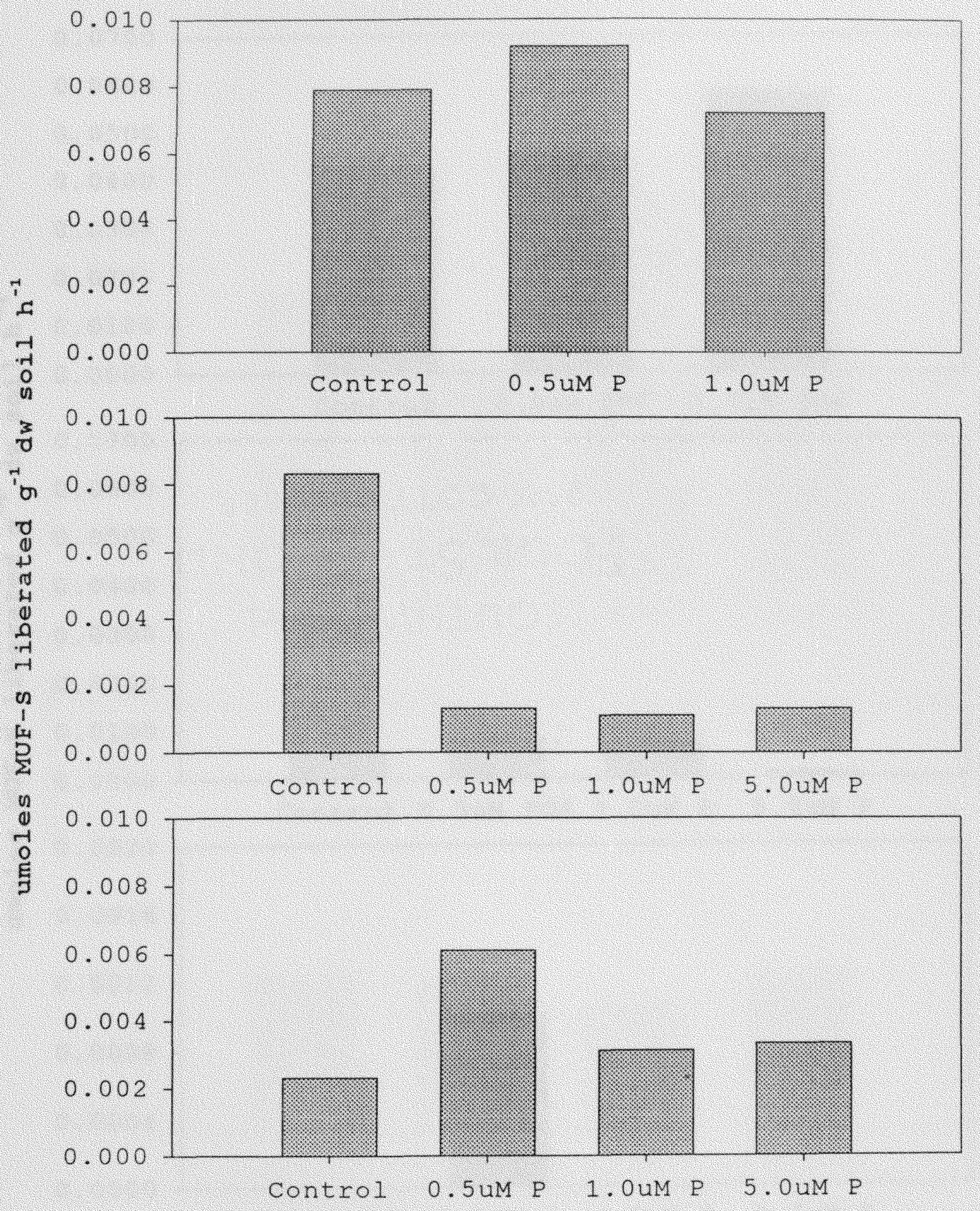

Eigure 10: Effects of $\mathrm{P}$ on sulfatase activity for experiments 1,2 , and 3 (top to bottom). 


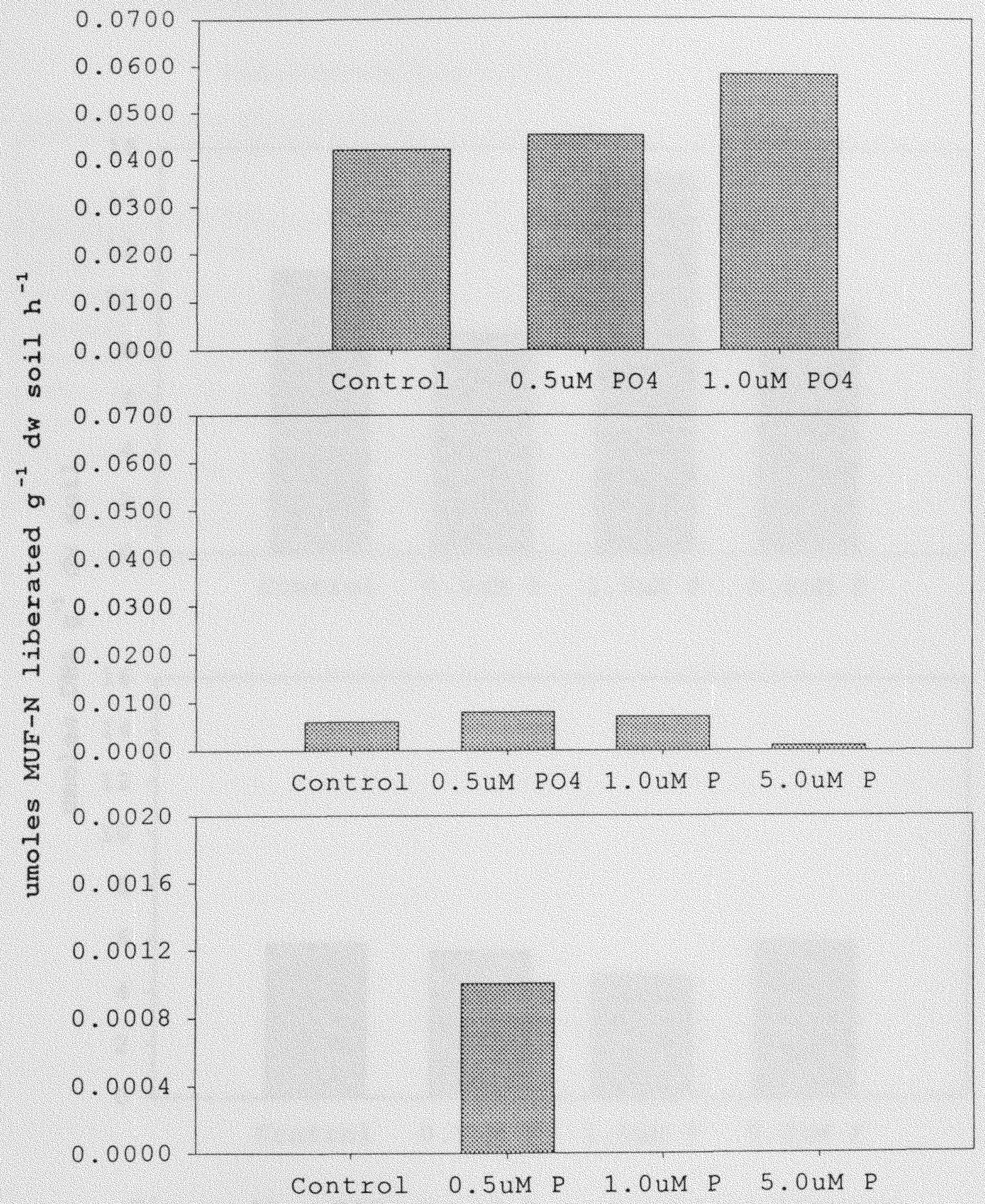

Figure 11: Effects of $P$ on glucoseaminidase activity for experiments 1,2 , and 3 (top to bottom). 


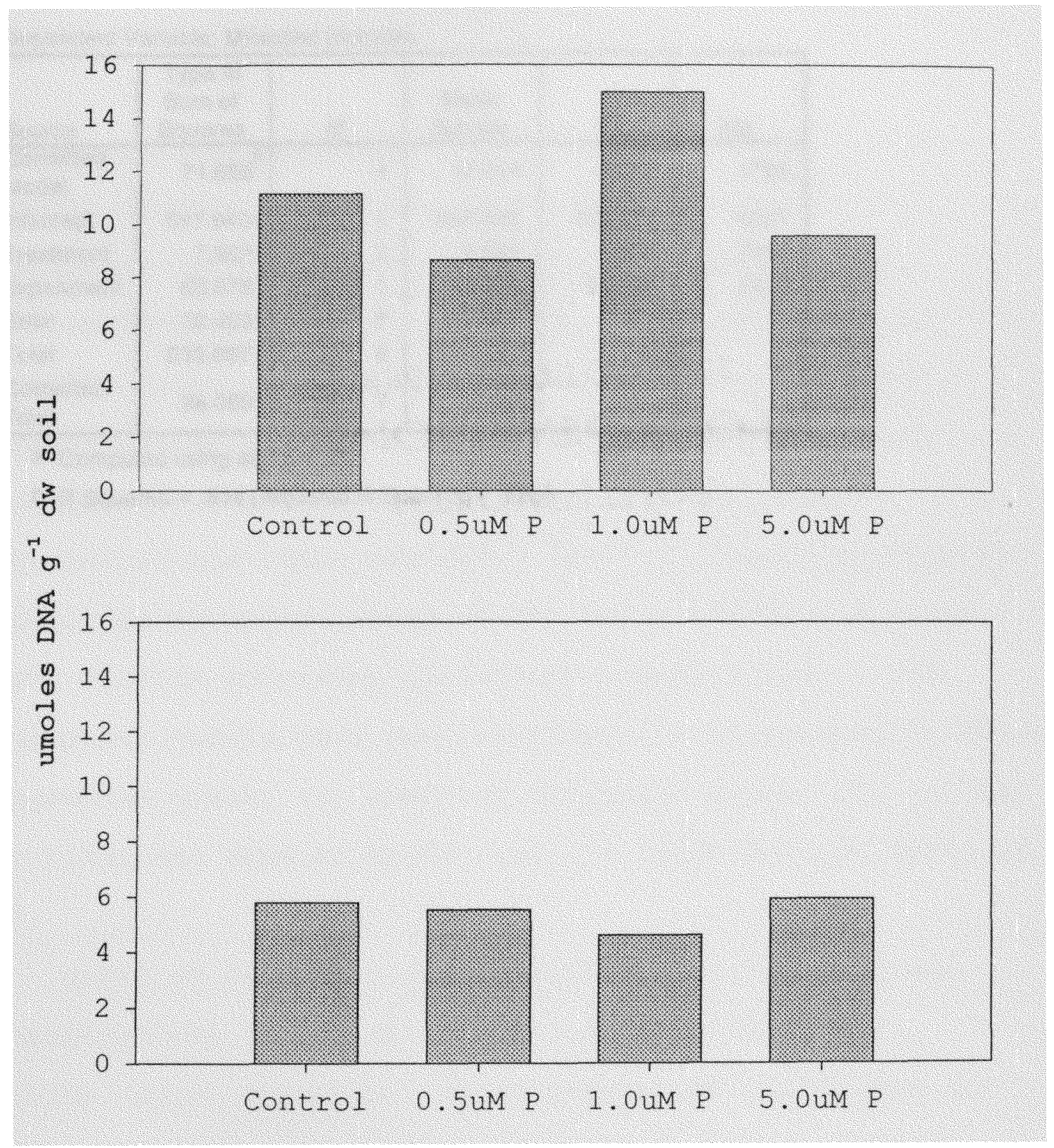

Eigure 12: Effects of $\mathrm{P}$ on microbial biomass for experiments 2 and 3 . 
Table 8: ANOVA table for the effects of $p$ on microbial biomass.

Tests of Between-Subjects Effects

Dependent Variable: Microbial Biomass

\begin{tabular}{|l|r|r|r|r|r|}
\hline Source & $\begin{array}{c}\text { Type III } \\
\text { Sum of } \\
\text { Squares }\end{array}$ & df & \multicolumn{1}{c|}{$\begin{array}{c}\text { Mean } \\
\text { Square }\end{array}$} & \multicolumn{1}{c|}{ F } & Sig. \\
\hline Corrected & $71.658^{b}$ & 4 & 17.914 & 3.277 & .1785 \\
Model & 547.640 & 1 & 547.640 & 100.178 & .0021 \\
Intercept & 7.982 & 3 & 2.661 & .487 & .7154 \\
Treatment & 63.676 & 1 & 63.676 & 11.648 & .0421 \\
Experiment & 16.400 & 3 & 5.467 & & \\
Error & 8 & & & \\
Total & 635.697 & 7 & & & \\
Corrected & 88.058 & & & & \\
Total & & & & \\
\hline
\end{tabular}

a. Computed using alpha $=.05$

b. $R$ Squared $=.814$ (Adjusted $R$ Squared $=.565$ ) 
dioxide and water (Killops and Killops, 1993). Therefore, the decreasing energy returns from anaerobic respiration and fermentation versus aerobic respiration does not appear to support an increase in microbial biomass.

\subsection{Mercury Methylation}

Several studies have shown that a specific set of conditions must occur for $\mathrm{Hg}$ to be methylated. The environmental factors include anaerobic conditions, a specific range of $\mathrm{Eh}$, and the presence of sulfate and organic matter. Three new conceptual models have been formulated to describe the process accounting for methylation and bioaccumulation of $\mathrm{Hg}$ in the South Florida Everglades Ecosystem based on the data collected for the South Florida Ecosystem Assessment Report (1988). The conceptual models have been developed to correspond to three geographic areas: (1) north of Alligator Alley, (2) between the Alley and Tamiami Trail, and (3) below Tamiami Trail in ENP.

North of Alligator Alley water quality constituent concentrations (e.g., TP, total organic carbon (TOC), sulfate $\left(\mathrm{SO}_{4}\right)$ ) are high. The nutrient concentrations are sufficiently high that the assimilative capacity of the natural system has been greatly exceeded, resulting in a shift in the natural community to a pollution tolerant community. MeHg concentrations in water and floating soil 
and periphyton are high, but concentrations in the mosquitofish are low. The Ecosystem Assessment Report (EPA, 1998) noted several factors that could contribute to this. TOC concentrations in LNWR could complex with MeHg and make it less biologically available for bioaccumulation. High $\mathrm{SO}_{4}$ concentrations in WCA-2 and anoxic conditions also increase the sulfide concentrations, which may complex with the inorganic $\mathrm{Hg}$ and reduce its availability for methylation; however, these processes are competing. In the canal system in this area the hypoxic and anoxic conditions have resulted in an incomplete food chain. The food chain in this geographic area consists primarily of grazers and filter feeders, resulting in fewer links in the food chain and lower biomagnification rates.

Between Alligator Alley and Tamiami Trail, $\mathrm{SO}_{4}$ concentrations were shown to have declined precipitously. TOC and TP concentrations have decreased to moderate levels. In the marsh, TP concentrations are between 10 and $20 \mu \mathrm{g} / \mathrm{L}$. Complexation of $\mathrm{Hg}$ with TOC or sulfide is reduced, and MeHg is available for bioaccumulation. Increased periphyton production, provides additional sites for increased methylation during the nocturnal period. This also results in increased bioaccumulation of MeHg within the periphyton community. More complete food webs, including both detrital and primary productivity-based pathways, provide additional links for $t$ he biomagnification of $\mathrm{Hg}$ through the food 
chain. Hg concentrations throughout the food chain, from periphyton to wading birds, are highest in this area. South of the Tamiami Trail TP concentrations have decreased below 10ug/L to near historical background levels so periphyton community production is less and is nutrient limited, as indicated by elevated APA levels. TOC and sulfide concentrations are low, so complexation with inorganic or organic $\mathrm{Hg}$ is limited. Both periphyton production and methylation rates have decreased. However, because the system is extremely oligotrophic, food webs are complex, with multiple pathways. Even though productivity is lower than areas north of Tamiami Trail, Hg bioaccumulation and biomagnification continues to occur because of the increased complexity of the food webs, including both detrital and productivity-based pathways. However, THg concentrations in mosquitofish are decreasing in the southern portion of the Everglades because methylation rates and MeHg concentrations have decreased. Based on the above findings it does appear that increased $\mathrm{PO}_{4}$ level does contribute to conditions that are necessary for mercury methylation in Everglades peat soils. Cored soil analyzed in this study are also being analyzed to determine if mercury methylation is higher in the reduced columns. The study is also being conducted using different carbon sources. 


\subsection{CONCLUSIONS AND RELEVANCE}

The results of this laboratory study indicate that in Everglades peat soil phosphorus enrichment may alter Cmetabolism resulting in a shift in the microbial communities from aerobically-dominated to anaerobically-dominated metabolic processes. This can have a number of consequences for nutrient cycling in pristine soils of the Florida Everglades. A shift to anaerobic metabolism will result in the use of alternate electron acceptors such as nitrate or sulfate instead of oxygen. Increased rates of denitrification may result in the removal of nitrogen from the soils (Koch and Reddy, 1992). Increases in sulfate reduction will result in increased production of hydrogen sulfide which is often toxic. Increased rates of methanogenesis may result in greater losses of $\mathrm{c}$ from the system in the form of $\mathrm{CH}_{4}$ (Cicerone and oremland, 1988). The occurrence and bioavailablity of mercury in sediments may be linked to the microbially mediated biotransformations of this element (Regnell et al. 1991 and stober et al. 1995). Anaerobic conditions, sulfate reducing bacteria, methanogens, and cobalamin mediated reactions have been implicated in the methylation of mercury. (Choi and Bartha 1993, Choi et al., 1994, Compeau and Bartha, 1985, Gilmour et al. 1992, and wood, 1974). The capacity of these or other anaerobes to methylate mercury is subject to regulation by nutrient input. Based on this $\mathrm{P}$ enrichment 
not only has the potential to alter $\mathrm{C}$ metabolism and nutrient cycling in these soils but may also create conditions that significantly facilitate the microbial transformation of inorganic mercury to its toxic form via methylation. 


\section{LIST OF REFERENCES}

Amador, J.A. and R.D. Jones. 1993. Nutrient limitations on microbial respiration in peat soils with different total phosphorus content. Soil Biology and Biochemistry. 25: 793-801.

Amador, J.A. and R.D. Jones. 1995. Carbon mineralization in pristine and phosphorus-enriched peat soils of the Florida Everglades. Soil science. $159(2): 129-141$.

Amador, J.A., G.H. Richany, and R.D. Jones. 1992. Factors affecting phosphate uptake by peat soils of the Florida Everglades. Soil science. $153(6): 463-470$.

Bodaly, R.A., R.E. Hecky, and R.J.P. Fudge. 1983. Increases in fish mercury levels in lakes flooded by the churchill River Diversion, Northern Manitoba. Can. J. Fish. Aquat. Sci. 41: 682-691.

Choi, S.C., and R. Bartha. 1993. Cobalamin mediated mercury methylation by Desulfovibrio desulfuricans LS. Appl.

Environ. Microbiol. 59:290-295.

Choi, S., T. Chase, Jr., and R. Bartha. 1994a. Enzymatic catalysis of mercury methylation by Desulfovibrio

desulfuricans. Applied and Environmental Microbiology. $60(4): 1324-1346$.

Compeau, G. and R. Bartha. 1985. Sulfate-reducing bacteria: Principal methylators of mercury in anoxic estuarine

sediment. Applied and Environmental Microbiology. $50(2)$ : $498-502$.

Davis, D.M. 1994. Phosphorus inputs and vegetation sensitivity in the Everglades. In S.M. Davis and J.C. Ogden (eds.). Everglades- the Ecosystem and its Restoration. $s t$. Lucie Press. pp. 659-692.

DeBusk, W.F. and K.R. Reddy. 1997. Turnover of detrital organic carbon in a nutrient-impacted Everglades marsh. soil sci. soc. Am. J. (Submitted).

DeBusk, W.F., K.R. Reddy, M.S. Koch, and Y. Wang. 1994. Spatial distribution of soil nutrients in a northern Everglades marsh: Water Conservation Area 2A. soil sci. Soc. Am. J. 58:543-552.

Davis, S.M., and J.C. Ogden. 1994. Everglades-the Ecosystem and its Restoration. st. Lucie Press. 826 pp. 
Delfino, J.J, T.L. Crisman, J.F. Gottgens, B.E. Rood and C.D.A. Earle. 1993. Spatial and temporal distribution of mercury in Everglades and okefenokee wetland sediments. Final project report. Univ. of Florida, Gainesville, FL.

Drake, H.L., N.G Aumen, C. Kuhner, C. Wagner, A. Griebhammer, and Schmittroth. 1996. Anaerobic microflora of Everglades sediments: effects of nutrients on population profiles and activities. Appl. Environ. Microbiol. pp. 486493.

Fenchel, T. and Blackburn T.H.,1979. Bacteria and Mineral Cycling. Academic Press. $225 \mathrm{pp}$.

Frederick, P.C. and M.G. Spalding. 1994. Factors affecting reproductive success of wading birds (Ciconiiformes) in the Everglades ecosystem. in S.M. Davis and J.C. Ogden (eds.). Everglades - the Ecosystem and its Restoration. St. Lucie Press. pp. 659-692.

Gilmour, C.C., E.A. Henry, and R. Mitchell. 1992. Sulfate stimulation of mercury methylation in freshwater sediments. Environ. Sci. Technol. 26: 2281-2287.

Grieb, T.M. C.T. Driscoll, S.P. Gloss, C.L. Schofield, G.L. Bowie, and D.B. Porcella. 1990. Factors affecting mercury accumulation in fish in the upper Michigan peninsula.

Environ. Toxicol. Chem. 9: 919-930.

Hand, J. and M. Friedman. 1990. Mercury, largemouth bass and water quality: A preliminary report. Florida Dept. Env. Reg., Tallahassee, FL. 28pp.

Hoppe, H.G. 1993. Use of fluorogenic model substrates for extracellular enzyme activity (EEA) measurement of Bacteria. In: Handbook of Methods in Aquatic Microbial Ecology. Eds: P.F. Kemp, B.F. Sherr, and J.J. Cole, Lewis Publishers. Boca Raton. pp. 423-431.

Jackson, T.A. 1988. The mercury problem in recently formed reservoirs of northern Manitoba (Canada): effects of impoundment and other factors on the production of methyl mercury by microorganisms in sediments. Can. J. Fish.

Aquat. Sci. 45: 97-121.

Jones, R.D, J. Trexler, and D.L. Childers. 1995. Numerical interpretation of Class III narrative nutrient water criteria for Everglades wetlands. Project scope of work. $50 \mathrm{pp}$. 
Killops, S.D., and V.J Killops, 1993. An Introduction to organic Geochemistry. Longman Scientific \& Technical.

$265 \mathrm{pp}$

Koch, M.S., and Reddy, K.R. 1992. Distribution of soil and plant nutrients along a trophic gradient in the Florida Everglades. Soil sci. Soc. Am. J. 56: 1492-1499.

Koch-Rose, M.S., K.R. Reddy, and J.P. Chanton. 1994. Factors controlling seasonal nutrient profiles in a subtropical peatland of the Florida Everglades. J. Env. Quality. 23: 526-533.

Loveless, C.M. 1959. A study of the vegetation in the Florida Everglades. Ecology. 40: 1-9.

Moore, P.A. and Reddy, K.R. 1994. Role of $\mathrm{Eh}$ and $\mathrm{pH}$ on phosphorus geochemistry in sediments of Lake okeechobee, Florida. J. Environ. Qual. 23: 955-964.

Nelson D.W. and L.E. Sommers. 1982. Total carbon, organic carbon, and organic matter. In Methods of soil Analysis. Part 2. A.L. Page, R.H. Miller, and D.R. Keeney (eds.). American Society of Agronomy, Madison. P 539-579.

Oremland, R.S. 1988. Biogeochemistry of methanogenic bacteria. in Biology of Anaerobic Microorganisms. J.B. Zehnder (ed.), John Wiley \& Sons, New York. pp 641-705.

Oremland, R.S., C.W. Culbertson, and M.R. Winfrey. 1991. Methylmercury decomposition in sediments and bacterial cultures: Involvement of methanogens and sulfate-reducers in oxidative demethylation. Applied and Environmental Microbiology. $57(1): 130-137$.

Qualls, R.G. and C.J. Richardson. 1995. Geochemistry of dissolved organic nutrients in the Everglades of Florida. Limnology and oceanography. (submitted).

Reddy, K.R., and E.M. D'Angelo. 1994. Soil processes regulating water quality in wetlands. In Mitsch, W.J. (ed.) Global Wetlands: old world and new. Elsevier. Science, Amsterdam. P. 309-324.

Reddy, K.R., R.D. Delaune, W.F. DeBusk, and M.S. Koch. 1993. Long-term nutrient accumulation rates in the Everglades. soil sci. Soc. Am. J. 57: 1147-1155.

Roelke, M.E., D.P Schultz, C.F. Facemire, S.F. Sundlof and H.E. Royals. 1991. Mercury contamination in Florida panthers. Prepared by the technical subcommittee of the Florida Panther Interagency committee. 
Rowel1, D.L. 1981. Oxidation and reduction.. In D.J. Greenland and M.H.B. Hayes (eds). The Chemistry of Soil Processes. John Wiley \& Sons Ltd. P. 401-461

Schmitt, C.J. and W.G. Brumbaugh. 1990. National Contaminant Biomonitoring Program: Concentrations of arsenic, cadmium, copper, lead, mercury, selenium, and zinc in U.S. freshwater fish, 1976-1984. Arch. Environ. Contam. Toxicol. 19: 731747 .

Scinto, L.J, M.K Nair, and R.D. Jones. 1999. Determination of microbial parameters in flooded peat soils using

flourescent compounds. Sixth Symposium of Biogeochemistry of Wetlands. July 11-14, 1999. University of Florida. Fort Lauaderdale, Florida.

Sengar, C.B.S., D.K. Soni, and A.L. Agarwal. 1989. Distribution of mercury in air, soil, and vegetation around a coal fired thermal power plant. Energy Env. Monitor. 5: $61-68$.

Silver, S., and M. Walderhaug. 1992. Gene regulation of plasmid-and chromosome-determined inorganic ion transport in bacteria. Microbiol. Rev. 56: 195-228.

Sinsabaugh, R.L. 1992. Enqymatic analysis of microbial pattern and process. Biol. Fertil. Soils. 17: 69-74.

Sinsabaugh, R.L., S. Findlay, P. Franchini, and D. Fischer. 1997. Enzymatic analysis of riverine bacterioplankton production. Limnol. Oceanogr. $42(1): 29-38$.

Solorzano, L. and J.H. Sharp. 1980. Determination of total dissolved phosphorus and particulate phosphorus in natural waters. $25(4): 754-758$.

Stober, Q.J., R.D. Jones, and D.J. Scheidt. 1995. Ultra trace level mercury in the Everglades ecosystem, a multimedia canal pilot study. J. Water, Air, soil pollut. 80:9911001.

Stober, J., D. Scheidt, R. Jones, K. Thornton, L. Gandy, D. Stevens, J. Trexler, S. Rathbun. South Florida Ecosystem Assessment, Monitoring for Adaptive Management: Implications for Ecosystem Restoration, Final Technical Report - phase I. EPA-904-R-98-002, October, 1998.

Swift, M.J., O.W. Heal, and J. M Anderson. 1979. Decomposition in terrestrial ecosystems. Univ. of California Press, Berkeley. 
Walker, W.W., 1991. Water quality trends at inflows to Everglades National Park. water Resources Bulletin. 27. $59-72$.

Westermann, P. 1993. Wetland and swamp microbiology. P. 215-238. In Ford, T.E. (ed.) Aquatic Microbiology.

Blackwell Scientific Publications.

Widdel, F. 1988. Microbiology and ecology of sulfate and sulfur reducing bacteria. in Biology of Anaerobic

Microorganisms. J.B. Zehnder (ed.). John Wiley and Sons, New York. pp. $469 .-585$.

Wood, J.M. 1974. Biological cycles for toxic elements in the environment. Science. 183: 1049-1052.

Zillioux, E.J., D.B. Porcella, and J.M. Benoit. 1993. Mercury cycling and effects in freshwater wetland ecosystems. Environmental Toxicology and Chemistry. 12: 2245-2264. 